体育学研究, 36：105-126, 1991.

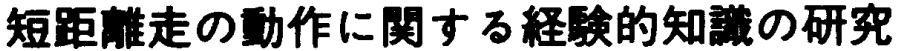

\author{
稲 垣 敦 ${ }^{11}$ 松 浦 義 行 ${ }^{1)}$ \\ Study of experiential knowledge regarding \\ movement of sprint running
}

Atsushi Inagaki ${ }^{1}$ and Yoshiyuki Matsuura ${ }^{1}$

\begin{abstract}
The purposes of this study were to examine the sex differences in structure of experiential knowledge regarding movement of sprint running, to estimate degree of subjective importance of the knowledge, and to clarify the relationship between both.

Thirteen hundred and six college athletes participated in this study. The first questionnaire was designed to determine the key items to investigate the structure of experiential knowledge regarding movement of sprint running and 224 items were chosen. The degree of importance of each item was assessed on 7-point rating scale. MDSCAL and COSCAL were applied to a dissimularity matrix in terms of each part of the body (i.e., head, arms, torso and legs), the extracted dimensions were rotated orthogonally based upon Normal Varimax criterion. Additionally, SMACOF, KARASCAL, IMDSCAL and ICOSCAL were applied to the data in terms of each part of the body so as to examine suitability of Weighted Euclidean Distance Model (WEM) and Simple Euclidean distance Model for each group (SEM) as representing the sex difference of structure. Furthermore, Schönemann's general Procrustes rotation was applied to ensure an appropriate comparison. similarity of the dimensions of male and female were evaluated by coefficient of congruence. Nextly, the degree of importance of each item was estimated and sex differences were evaluated. Lastly, the relationship between the degree of subjective importance and the dimension was evaluated with multiple regression analysis.

Analysis of data indicated that three-dimensional spaces for head and torso, and four for arms and legs were good enough to explain the structure of experiential knowledge in each group. Thus the number of attributes systematizing knowledge are equal in both groups. Obvious differences were recognized in goodness of fit between SEM and WEM, so that sex differences in structure were assumed to be qualitative. It could be infered that the degree of importance of each item estimated in this study reflects specific knowledge regarding movement of sprint running because of high similarity between the results and general opinion of specialists in this field. High multiple correlations were obtained with regression analysis in all parts of the body, so that the degree of subjective importance was assumed to be determined with linear function of the dimensions obtained in this study.
\end{abstract}

Key words: sprint running, experiential knowledge, MDS

(Japan J. Phys. Educ., 36: 105-126, September, 1991.)

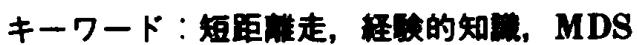

I. 緒

近年，専門家の経鏂的知識が重要視されてい
る領域において，その経検的知識を抽出して有 奻に利用しよらとする研究が進められ，既に実 用化の段階に入っている (Duda et $\mathrm{al}^{\mathrm{s}}{ }^{\mathrm{s}}$, Feigenbaum"), Lindsay et al. ${ }^{29)}$,

1）筑波大学体育科学系

1. Institute of Health and Sport Sciences, University of Tsukuba, 干305 荻城県つくば市天王台 1-1-1 Tennodai, Tsukuba-city, Ibaraki (305) 
$\mathrm{McDermott}^{31)}$, Pople et al. $\left.{ }^{33)}\right)$. 運動やスポー ツに関しても，動作，戦術，トレーニング、コ ンディショニング, 選手の選抜，選手の将来性 の予測などに関する専門家の経験的知識は有効 に利用されていないばかりか，それを蓄積して 体系的に整理し，評価・精選しようとする試み あほとんどないのが現状である。

さて，運動技能学習においては，特に動作に 関する運動感覚的情報やそれに基つく経験的知 識が重要となる。すなわち, Neisser ${ }^{32)}$ の知覚循 環理論, Schmidt ${ }^{35.36)}$ のシェマ理論, Adams ${ }^{1,2)} の$ 閉回路理論においても位置つけけられるよらに, 動作の正プロセスにおいては，このレベルの 情報により「目標としている動作」を設定し， 「現状の動作」を把握し，両者の「差異」を検出 して「動作の正方向」を決定している。また， 専門家の経時的知識は力学的研究を適用すべき 有意味な点を示唆できる可能性も含んでいる。 さらに，実際の指導においても，教示やメンタ ルプラクティスにおける想起内容を提供できる と考えられる。 また，好ましい教示を精選する ことは，指導経験の少ない指導者の指丵の質を 高める上で頁献するであろう。したがって，動 作に関寸る経験的知識を専門家から抽出して利 用することは，指严法の発展と運動技能学習の 効率化を促進すると考えられる。

しかし，専門家の経検的知識は各個人の限ら れた運動経検に依存している部分が多く，また， 認知・思考といらような主観的要素や体格・体 力などの個人の特性の影䉕を受けていると考え られる。したがって，ある特定の専門家の経験 的知識のみを重視するのではなく，多くの専門 家の経験的知識から一般的な知識を抽出する必 要があろう。このような点から, 稲垣はが11-23) は，知識を「動作」に成する知識に限定し，具 体的な運動として身体をすばやく移動させると いう点で多くのスポーツの基礎であり，また， スキルが closed (Poulton ${ }^{34)}$ ) であることから， 動作に関する感覚的情報が相対的に重要である わのの一つとして「短距離走」を採り上げて研 究を進めてきた。
稲垣ほが-22)は経験的知識を整理するため に，専門家が経険的知識を意識的に，あるいは 無意識的に体制化するために用いている観点を 明らかにすることを試みた。このため，知識を 陸上競技選手から抽出し，短距離走選手の重要 度評価の情報を利用して距離モデルの下で情報 を集約し，知識を体制化している特性を抽出し た。さらにここの知識構造の被験者に関する一 般性を検討するため，被検者の特性として「運 動経験」と「短距離走能力」を採り上げた。そ して，この特性を端的に反映していると考えら れる標識として「専門種目」と「100 $\mathrm{m}$ 走タイ ム」を採用し，この標識によって分類された集 団間の知識構造の等質性を検討した。 その結果, 知識構造が質的に異なっていたことから知識構 造の被験者に関する一般性の仮説は裹却され， 被験者の運動経験や短距離走能力が知識構造, あるいは知識の棈造化に関与していることが明 かにされた。

しかし，高い運動パフォーンスは個人の体 格・体力条件（特性）下における最適な動作系 列によって達成されると考えることができる。 したがって，動作と相互作用を持つと考えられ る動作に成する知識は，体格・体力に関連する 性の要因とも网連性があると考えられる。そこ で，本研究では知識構造の性差を検討すること を第 1 の目的とした，具体的には，(1)知識構造 に性差があるか，(2)性差があるとすれば量的差 異か（知識を体制化する特性を重視する程度の 差異)，それとも質的差異か(知識を体制化する 特性自体の差異)，(3)具体的にどのように異 なっているか, とい53 点を検討した。

また，経験的知識を精選するためには，専門 家の各知識（具体的には，項目）自体の重要度 に関する情報を抽出することが直接的であり， かつ実用的であろう。なぜなら，これらの動作 に咸する経験的知識を有効に利用しようとする 場合, フィジルプラクティスにせよ，メンタ ルプラクティスにせよ, 学習者に与えて学習者 がこの内容を意識上の目標として利用する形式 を採る可能性が高いと考えられるからである。 
そこで，専門家による各知識の重要度評価から 各知識の主観的重要度を推定することを，第 2 の目的とした。

さらに，膨大な量の経検的知識の情報を集䄪 するためには, 各知識 (項目) 自体の重要度で はなく，専門家が各項目の重要度を評価する際 に，知識に含まれている「特性」のうちどの「特 性」を重視しているかといら点を明らかにする ことが重要であろ5．また，その「特性」のど ちらの方向（に対応する内容）を肯定的に評価 しているかといら情報も重要であろう。そこで， 上記の主観的重要度が知識に含まれているどの よらな「特性」に基ついて決定されているかを 明確化することを，第 3 の目的とした。なお， この場合の「特性」は上述した体制化の特性に 相当する。なぜなら，上記の一連の研究におい ては，専門家が短距離走パフォーマンスに対す る知識の重要度の評価に利用していない特性 (つまり,専門家が短距離走パフォーマンスと関 係がないと考えている特性）を抽出することが 有効ではないことから，この種の特性を無視し， 重要度評価のデータから知識構造を推定すると いら手続きを採っているからである。したがっ て，ここで抽出される体制化の特性は重要度評 価に関与寸る特性に限定され，直接的には「重 要度評価に利用された特性」を示するのだから である，そこで，主観的重要度が各体制化の特 性の線形関数により決定されるといら構造を仮 定し，この仮説の妥当性を検討した。そして， この仮説の妥当性が保証された後に, 推定され た線形関数のハランータから主観的重要度に対 する各体制化の特性の関連の程度と闺連の方向 性を推定した。

稲垣ほか23)は，既に加速疾走局面の動作に関 する経験的知識においてこれらの点を検討し た。 そこで，本研究では，中間疾走局面に閣し て同様な検討を加えるとともに，加速疾走局面 と中間疾走局面の比較から疾走局面に関する一 般性を検討することも目的とした。

以上のように，本研究は，

(1) 経検的知識を体制化している特性の抽出
(2) 各知識の主観的重要度の推定

(3) 主観的重要度を決定する上での特性の重 要度の推定

(4) (1)-(3)の性差の検討

(5) (1)一(3)の疾走局面間差の検討 の 5 つを目的とする。

\section{II. 方 法}

まず，短距離走の中間疾走局面の動作に関す る経検的知識を自然言語（日本語）の形式で抽 出するため，それらの知識を身体部位別(頭部， 上肢部，体幹部，下肢部）に箇条書きで応答す る自由記述法による第一次質問紙を作成し，大 学の陸上競技選手 1,306 名に郵送で実施した結 果，回収率は 33.5\%（438 件）であった。この ようにして収集された知識については，内容の 不明瞭なものや同じすのは削除し，一項目の中 に評価の対象となる特性が袮数とならないよう に項目化した結果, 頭部 34 , 上肢部 67 , 体幹部 34, 下肢部 89 の計 224 項目に整理された。この 際，2つ以上の身体部位の動作の関係を強調し ている項目についてはそのままにし，特に強調 していると考えられる方の部位に含めた。

次にこのよ5にして得られた各項目の重要度 を 7 段階評定法により評価する第二次質問秖を 作成し, 第一次質問紙とはは等しい標本 1,278 名 に同一の方法で実施した結果，回収率は $42.5 \%$ （543 件）であった。このうち本研究では，短距 離走動作の経検が豊富であり，かつ，高い短距 離パォーマンスを有しているという点で，短 距離走動作の専門家であると考えられる短距離 走選手，男子 84 名，女子 99 名を分析の対象と した.

まず，性別に身体部位ごとの項目間相成行列 を算出し，下に示したよらに定義した項目間の 非類似性を要素とする非類似性行列を算出し た。

$$
o_{1 / \mathrm{k}}=1.0-\mathrm{r}_{\mathrm{j} \mathrm{k}}
$$

但し， $\mathrm{o}_{1 \mathrm{jk}}$ と $\mathrm{r}_{\mathrm{ijk}}$ は，i群 $(\mathrm{i}=1 \sim \mathrm{N} ; ； \mathrm{~N}$ は群数 でこの場合 2 となる）における項目 $\mathrm{j}$ と $\mathrm{k}$ の非 類似性とPearsonの積率相関係数をそれぞれ 
示す ( $\mathrm{j}, \mathrm{k}=1 \sim \mathrm{n} ; \mathrm{n}$ は項目数).

知識構造の性差の検討では,

(1) 性差がない

(2) 是的差異がある

(3) 質的差異がある

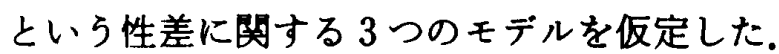
ここで，(1)は知識を体制化している特性が共通 で, 各特性を重視する程度も等しい，(2)は知識 を体制化している特性が共通だか，各特性を重 視する程度が異なっている，(3は知識を体制化 している特性自体が異なっていることをそれぞ れ示している。そして，それぞれの場合に相当 するモデルを道合し，その適合度から性差がど のモデルにおける差異かを推測するという手続 きを採った，具体的には，因子モデルよりも距 離モデルの方が妥当であるとい5知見 (稲垣 $\left.{ }^{21)}\right)$ から，本研究でもユークリッド距離モデル（高 根 $\left.{ }^{41)}\right)$ の仮定の下で仮説の検討するので, (1)は男 女に単純ニークリッド距離モデル（Simple Euclidean Distance Model ; 以下,「SEM」と略 す),(2は男女に重み付きユークリッド距離モデ ル (Weighted Euclidean Distance Model ; 以 下,「WEM」と略す，(3は性別に SEMを商合 することに相当する。なお，前処理により構成 された表面尺度としての非類似性は原型尺度と しての項目間距離と比例阙係を有していると仮 定することは非現実的であり，また，測定諯差 や標本誤差も含まれている。したがって，本研 究では非類似性を間隔尺度と順序尺度を仮定し た場合（実漈には，「順序情報のみを利用した場 合」と記すべきであろら）の両方においてモデ ルの妥当性を検討した。また，客钼的に適合度 を比較するためには，共通した目的関数を用い る MDS (Multidimensional Scaling)の暗用に よって得られた目的関数の值をるって評価する ことが要求される。そこで，全て距崔において 目的闺数を定義する手法を採用した。

まず，制約条件の爱い順にモデルを暗合させ るため, 男女別に SEM を適合させる(3)に相当 する).この場合のモデルは,

$$
g\left(o_{i j k}\right)=f\left(d_{i j k}\right)+e_{i j k}
$$

であり、これを最小二乗基準の下で適合させる。 但し, $d_{i j k}, e_{i j k}$ は i 群における項目 $\mathrm{j}$ と $\mathrm{k}$ の単純 ユークリッド距離とその誤差であり， $\mathrm{g}$ と $\mathrm{f} は$ それぞれ。とdの取暗変換（関数）を示す。非 類似性に間隔尺度を仮定した場合には，g 類 似変換( similar transformation)で, $\mathrm{f}$ はアフィ ン変換 (affine transformation) である。また， 順序尺度を仮定した場合には，gは単調変換 (monotonic transformation) であり，f 変換となる，実際のモデルの適合には，前者で は COSCAL (Cooper $\left.{ }^{6)}\right)$, 後者ではMDSCAL (Kruskal ${ }^{26,27)}$ )を用いた。

次に，男女にWEM を適合させる（2)に相当 する)。この場合のモデルは,

$$
\mathrm{g}\left(\mathrm{o}_{\mathrm{ijk}}\right)=\mathrm{f}\left(\mathrm{d}_{\mathrm{ljk}}\right)+\mathrm{e}_{\mathrm{ijk}}
$$

であり,これを取小二乗基準の下で適合させる。 但し，この場合は $\mathrm{d}_{1 \mathrm{jk}}$ が重み付きュークリッド 距雄であるという点で上と異なっている，実験 のモデルの適合には，间隔尺度を仮定した場合

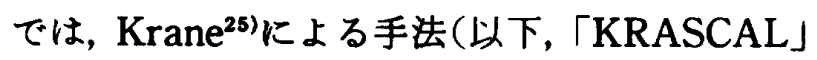
と略す)，順序尺度を仮定した場合には SMACOF (Scaling by MAximizing a COnvex Function; de Leeuw and Heiser ${ }^{7)}$ )を用いた。 最後に, SEM を男女に適合する(1)に相当す る).この場合のモデルは,

$$
\mathrm{g}\left(\mathrm{o}_{\mathrm{ijk}}\right)=\mathrm{f}\left(\mathrm{d}_{\mathrm{jk}}\right)+\mathrm{e}_{\mathrm{ijk}}
$$

でありこれを取小二乗基準の下で適合させる。 但し,この場合は $\mathrm{d}_{\mathrm{jk}}$ 単純ニークリッド距離で, $\mathrm{d}_{\mathrm{jk}}=\mathrm{d}_{\mathrm{ljk}}(\mathrm{i}=1 \sim \mathrm{N})$ であるといら点で上と異 なっている，実際のモデルの適合には，間隔尺 度を仮定する场合には上記の COSCALを個人 差モデルに抬張した手法（以下，「ICOSCAL」 と略す)，順序尺度を仮定した場合には, IMDSCAL (Kruskal ${ }^{26,27)}$ )を用いた。

なお，初期布圈は局所最小や退化した解に陥 る確率が少なく，かつ，少ない反復回数で収束 するといら点で優れており(Arabie ${ }^{3)}$, Clark $^{5)}$, Lingoes and Roskam ${ }^{30)}$, Spence ${ }^{38,39)}$, Spence and Young $\left.{ }^{40}\right)$, rational strating configuration と呼ばれていることから，全ての解析で Togerson ${ }^{42)}$ 計肯的 MDSによる同一次元数 
の布置を用いた。また，間隔尺度を仮定した場 合の関数 $\mathrm{f}$ と順序尺度を仮定した場合の関数 $\mathrm{g}$ には群間差を許容した。つまり, 単調関数と加 算定数には群間差を許容したことになる。各モ デルの適合度の比較にはStressl の形式を用い た。但し，間隔尺度を仮定した場合にはその仮 定上, 非類似性の平方和で基準化したものを用 いた。つまり，

$$
\text { no fit }=\left[\Sigma\{\mathrm{g}(\mathrm{o})-\mathrm{f}(\mathrm{d})\}^{2}\right.
$$

$\left./ \Sigma\{g(o)\}^{2}\right]^{1 / 2} \ldots \ldots . . .$. 間隔尺度の場合 no fit $=\left[\Sigma\{g(o)-f(d)\}^{2}\right.$

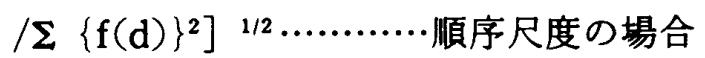

さて, 湘定誤差や標本差による布置の変動に 基つくく次元の変動を考虑して次元を比較するた めには, Schönemann and Carroll ${ }^{35)}$ の general Procrustes rotation を適用した。この変換は,

$$
\begin{gathered}
\boldsymbol{\psi}=\operatorname{tr}\left[\left(\mathrm{X}_{\mathrm{t}}-\alpha \mathrm{X}_{\mathrm{r}} \mathrm{T}-\mathbf{1}_{\mathrm{n}} \mathrm{c}^{\prime}\right)^{\prime}\right. \\
\left.\left(\mathrm{X}_{\mathrm{t}}-\alpha \mathrm{X}_{\mathrm{r}} \mathrm{T}-\mathbf{1}_{\mathrm{n}} \mathrm{c}^{\prime}\right)\right]
\end{gathered}
$$

を最小化する $\alpha$ (布置扗大の比率を示すスカ ラー), $\mathrm{T}$ (直交回転行列), c (原点移動べクト ル）を求めようとする手法である（但し， $\mathrm{X}_{\mathrm{t}}$ は ターゲット行列, $\mathrm{X}_{\mathrm{r}}$ は被変換行列, $1_{\mathrm{n}}$ は 1 を要 素とする n 次元ベクトルを示す). なお，次元の 類似性は, coefficient of congruence (Burt ${ }^{4}$, Tucker ${ }^{43)}$, Wringley and Newhaus ${ }^{44)}$ )を用い た (Inagaki and Matsuura ${ }^{16)}$, 稲垣・松浦 ${ }^{18)}$ ). さらに，空間における有意味な次元を同定する ためには，因子分析で多用されている Normal Varimax 基準 (Kaiser ${ }^{24)}$ ) による回転を布置の セントロイドを中心として適用した。

さて, 次に, 各項目の主穊的重要度を推定す るわけであるが，本研究では，高い短距離走能 力を有し，かつ，その運動経験が豊富であると いう点で短距離走の「動作」の専門家であると 考えられる短距離走選手の平均的評価という意 味で，短距離走選手の母集団の平均值として主 観的重要度を定義した。したがって，正規性の 仮定の下で, 不偏性, 有効性, 一致性, 十分性, 最尤性といら特性を满たすといら点から，標本 平均により推定した。

最後に，この主観的重要度が体制化の特性の
線形関数によって決定されているという仮説を 検討する。これは, 幾何学的には主観的重要度 の方向を示すへクトルを知識空間に位置づける ことに相当する，したがって，各体制化の特性 （次元）を独立変数とし，主観的重要度を従属変 数とした線形重回㷌分析を適用した。なぜなら， 本研究では，求めるへクトルへの各項目の射影 と主観的重要度間に設定された最小二乗基準の 下でべクトルを設定しようとするからである。 したがって，各体制化の特性の再門家が肯定的 である方向は, 重回㷌分析の結果得られた回㷌 係数の符号により判断し，また，関与の程度は 標準偏回㷌係数, 貢献度, 知識空間へ射影した 主観的重要度べクトルとの角度などから評価す れば良い。

\section{III. 桔果と考菜}

\section{1. 知境棤造の検郡}

まず，最す制約条件の緩いSEMを男女別に 適合するためにMDSCALを性別に適用した 結果, Kruskal and Wish ${ }^{28}$ による基準から，男 女とも共通に頭部と体幹部では 3 次元解, 上肢 部と下肢部では 4 次元解が採用された。このこ とは, 直接的には短距離走動作の専門家である と考えられる短距離走選手の男女いずれすが動 作に関する経験的知識から抽出した情報の重要

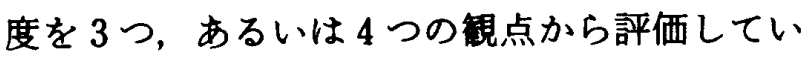
ることを示唆している。これらの情報の重要度 評価はその情報に夙連する知識をすとにおこな われているので，各部位の動作に関する知識が

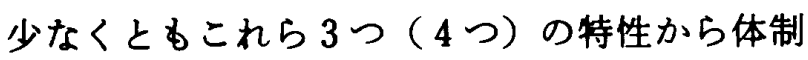
化されていると推測される。ささらに, 知識の「重 要度」といら特性が短距離走能力を高めること を目指している者にとって最す重要な特性であ ることを考感すれば，上記の特性が経検的知識 を体制化する上で特に重要な特性であると考え られる。このように，各知識の相互開連性を距 離空間で表現するために等しい次元数が必要で あるといら点から，経検的知識の情報集約の程 度には大きな性差はないと言えよう。また，稲 垣ほか23)による加速疾走局面の解析でも同様な 
衰 1.MDSCAL の適用によって男女別にSEM を適合して得られた解における Stressl，非類似性と距離の相闺係数，説明率

\begin{tabular}{|c|c|c|c|c|c|c|}
\hline \multirow{2}{*}{$\begin{array}{c}\text { 部位 (次元数) } \\
\text { 群 \指標 }\end{array}$} & \multicolumn{3}{|c|}{ 頭部（ 3 次元） } & \multicolumn{3}{|c|}{ 上肢（ 4 次元） } \\
\hline & Stressl & $\mathbf{r}$ & $r^{2} \times 100$ & Stressl & $\mathbf{r}$ & $r^{2} \times 100$ \\
\hline 男 子 & .139 & .813 & 66.1 & .132 & .804 & 64.6 \\
\hline 女 子 & .164 & .772 & 59.6 & .132 & .795 & 63.2 \\
\hline \multirow{2}{*}{$\begin{array}{c}\text { 部位（次元数） } \\
\text { 群 \指標 }\end{array}$} & \multicolumn{3}{|c|}{ 体幹（ 3 次元） } & \multicolumn{3}{|c|}{ 下肢 ( 4 次元) } \\
\hline & Stressl & $\mathbf{r}$ & $r^{2} \times 100$ & Stressl & $\mathbf{r}$ & $r^{2} \times 100$ \\
\hline 子 & .128 & .841 & 70.7 & .140 & .837 & 70.1 \\
\hline 子 & .121 & .850 & 72.3 & .140 & .779 & 60.7 \\
\hline
\end{tabular}

基準で次元数を決定しているが，全ての部位で 3 次元解が採用されている。このことは，中間 疾走局面における動作が加速疾走局面よりも主 観的に多くの観点から捉えられていることを示 している。この差異は，第一次調査で収集し， 編集された項目数にも表れている.すなわち, 対象とした標本が全く同じであるこるにすかか わらず，加速疾走局面では 147 項目（22，48, 33，44）で中間疾走局面では 224 項目 (34，67, 34，89）である（カッュ内は項目数の内訳で， 頭部，上肢部，体幹部，下肢部の順）.

表 1 は,男・女で採用された解における Stressl, 非類似性と距離との相阅俰数, 説明率を示して いる. Kruskal の基準を採用したことから Stressl は,いずれの身体部位においても 0.2 末 満である。また，非類似性と採用された空間に おける距離との相成係数は $0.772-0.850$ であ ク，説明率も59.6\%-72.3\%と高い值を示し ている。これは, 稲垣はが23にによる加速疾走局面 の解析において得られた結果と同程度である。 このように高い精度でデータを説明できるとい ら点から, 短距離走の中間疾走局面の動作に関 する経釦的知識間の成連性の変動の主要な部分 が反映されていると言えよ5。また，少ない次 元でこれが達成されており，経験的知識の表現 モデルとしての距離モデルの妥当性す暗示して いる.

そこで，この男女における知識構造をより包 括的なモデルで説明（表現）できる可能性を検
討するため，前述の各モデルを䔔合した．表 2 は，次元数を上述した数に固定して各 MDS 手 法を適用して得られた解における非適合度を示 したすのである。この表では，同一尺度水準を 仮定したモデル群内では上方はど制約条件が喛 しく，下方ほど制䄪条件が緩いモデルとなって いるので，当然のことながら下方ほど值が低い ことが認められる，そこで，制約条件を緩くす ることによる非適合度の低下を比教してみる。 まず，間隔尺度を仮定した場合において，次元 に性差を許容しないモデル（第 1 行目）から次 元に対するウェイトのみに性差を許容するモデ ル（第 2 行目）への低下と，次元に対するウェ イトのみに性差を許容するモデル（第 2 行目） から次元に性差を認めるモデル（第 3 行目）へ の低下を比較すると，頭部と体幹部では前者の 方が著しく大きいが，反対に上肢部と下肢部で は同程度かあるいは後者の方が大きいことが認 められる。また，順序尺度と仮定した場合には， 男子の下肢部を除いて前者の方が著しく大きい ことが認められる。この結果は，単純に見れば WEM，すなわち男女における次元の特性が全 て等しく，各次元を重視する程度に差異がある モデルを仮定することが適切であることを示唆 するすのである。しかし，非䔔合度の低下は制 約条件の緩和の程度も考慮して評価すべきであ ろら。そして，これは表現するために必要とす るパラメータ数, つまり推定されるパラメータ 数の増加で評価することが考えられる。すると， 
衣2、各モデルを適合した場合の Stressl”)

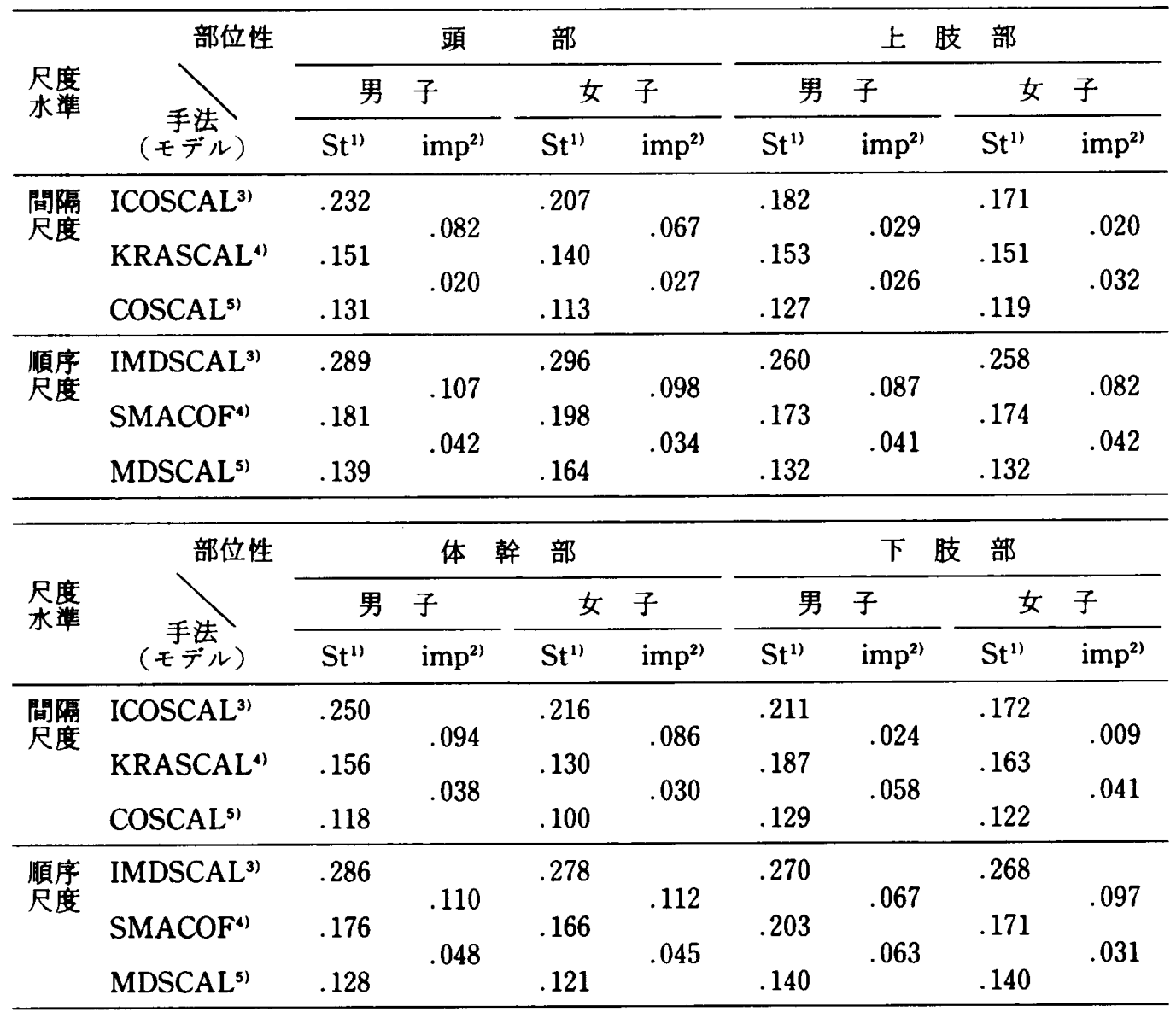

1）败密にはStressl とは異なる（本文参照）

2）モデルの制約条件を釉和することによる Stressl の改善五

3）男女に SEM を適合（男女に同一次元を仮定するモデル）

4）男女にWEM を適合（男女同一次元で，次元に対するウェイトの差異のみを許容する モデル)

5）男女別にSEM を適合（男女に異なった次元を許容するモデル）

ハラメータ数は, 次元に性差を許容しないモデ ル（第 1 行目）では $\mathrm{n} \times \mathrm{m}$ ，次元に対するウェイ トのみに性差を許容するモデル（第 2 行目）で は $\mathrm{m}(\mathrm{n}+\mathrm{N})$, 次元に性差を認めるモデル（第 3 行目) では $n \times m \times N$ である。但し， $n, m$, $\mathrm{N}$ はそれぞれ項目数 (=34, 67，34 or 89), 次 元数 (=3 or 4), 群数 (=2) である.したがっ て，パラメータ数の増加は, $\mathrm{m} \times \mathrm{N}$ と $\mathrm{m}(\mathrm{n} \times$ $\mathrm{N}-\mathrm{n}-\mathrm{N})$, つまり $2 \mathrm{~m}$ と $\mathrm{m}(\mathrm{n}-2)$ となり $(\mathrm{N}=2), \mathrm{n}=4$ ならばハララメータの増加数が等 しくなるが， $\mathrm{n} \geq 34$ と大きいことからいずれの 部位に打いても媵者のパラメータ数の增加の方 が著しく大きい、にもかかわらず，前者の非適 合度の低下が大きい傾向があるという結果は，
WEM の妥当性を支持するむのである.

しかし，WEMの適合においては SEM と同 一次元数を用いていることに注意すべきであ る。これは，男女の「全ての次元」の特性は等 しい（但し，ウェイトは異なるが）とい5条件 を課していることになる。しかしながら，いく つかの次元が男女共通であるという場合す考え られこのよらな場合でも上記のよらな結果が 得られる可能性が高い。特に，固有次元が共通 次元より相対的に少なければ，上記のよ5に後 者の非適合度の低下は少ないはずである。この 点を検討するためには，さらに次元数を多くし たWEMを適合することが考えられる。つま り,ある次元は男女とも高いウエイトを有し(共 
表 3、男女別にSEM(MDSCAL)を適合して得られた次元の回転後の coefficient of congruence

\begin{tabular}{|c|c|c|c|c|c|c|c|c|c|c|}
\hline \multicolumn{3}{|c|}{ 部位 \回転法 } & \multicolumn{4}{|c|}{ Varimax } & \multicolumn{4}{|c|}{ Procrustes } \\
\hline \multirow{2}{*}{\multicolumn{2}{|c|}{ 群 }} & \multirow[b]{2}{*}{ 次元 } & \multicolumn{2}{|r|}{ 男 } & \multicolumn{2}{|l|}{ 子 } & \multicolumn{4}{|c|}{ 女 } \\
\hline & & & 1 & & & 3 & 1 & & & 3 \\
\hline \multirow[t]{3}{*}{ 頭部 } & & 1 & 067 & \multicolumn{2}{|c|}{-325} & 464 & 447 & \multicolumn{2}{|c|}{-095} & 365 \\
\hline & 女子 & 2 & 400 & \multicolumn{2}{|c|}{060} & 540 & -075 & \multicolumn{2}{|c|}{485} & -205 \\
\hline & & 3 & -351 & \multicolumn{2}{|c|}{412} & -382 & 283 & \multicolumn{2}{|c|}{-202} & 665 \\
\hline \multirow[t]{3}{*}{ 体幹 } & & 1 & -724 & \multicolumn{2}{|c|}{178} & 369 & 723 & \multicolumn{2}{|c|}{-111} & -320 \\
\hline & 女子 & 2 & 093 & \multicolumn{2}{|c|}{-581} & -282 & -093 & \multicolumn{2}{|c|}{555} & 218 \\
\hline & & 3 & 040 & \multicolumn{2}{|c|}{156} & -071 & -320 & \multicolumn{2}{|c|}{261} & 333 \\
\hline \multicolumn{3}{|c|}{ 部位 \回転法 } & \multicolumn{4}{|c|}{ Varimax } & \multicolumn{4}{|c|}{ Procrustes } \\
\hline \multirow{2}{*}{\multicolumn{2}{|c|}{ 群 }} & \multirow[b]{2}{*}{ 次元 } & & 男 & 子 & & & 女 & 子 & \\
\hline & & & 1 & 2 & 3 & 4 & 1 & 2 & 3 & 4 \\
\hline \multirow[t]{4}{*}{ 上肢 } & & 1 & -279 & -450 & 142 & -248 & 804 & 043 & -037 & 139 \\
\hline & 女子 & 2 & -447 & -167 & -040 & -225 & 043 & 480 & -049 & 229 \\
\hline & & 3 & 061 & 051 & 285 & 030 & -039 & -052 & 323 & -010 \\
\hline & & 4 & -740 & 153 & 055 & -007 & 145 & 237 & -010 & 225 \\
\hline \multirow[t]{4}{*}{ 下肢 } & & 1 & -546 & 200 & -284 & -222 & 503 & -147 & 238 & 188 \\
\hline & 女子 & 2 & 079 & -079 & 202 & 109 & -181 & 437 & -086 & 035 \\
\hline & & 3 & 125 & -400 & 062 & -079 & 278 & -082 & 328 & 177 \\
\hline & & 4 & 279 & 055 & 266 & 177 & 239 & 036 & 193 & 200 \\
\hline
\end{tabular}

注）值は1,000倍してある

通次元)，他の次元では男女いずれかが高いウエ イトを有するが他方はウェイトがほとんどゼロ に近い（固有次元）といらように表現可能であ るからである。しかし，男女の固有次元が互い に独立に近くなれば，このような結果は得られ ない.そこで, 男女別に SEM を適合して得られ た次元の比較を試みた。表 3 の左の例は, MDSCALによって得られた次元に Normal Varimax 回転を適用して得られた次元間の coefficient of congruence を示している（座標 の原点をセントロイドに設定してあるので Pearsonの積率相関係数と等しい).表に示され ているように，いずれの部位でも 1 つあるいは $2 つ の$ 類似した次元の組合せが認められるが, その類似度はあまり高くなく，また，数数の次 元と中程度の類似性を示している次元も認めら れる.しかし，解析に用いられたデータには， 標本誤差や測定誤差などの偶然誤差が含まれて
いると考えられ，これが次元の位嘈（設定）に 影算していると考えられる。そこで，この点を 考虑し，男子の次元をターゲットとして女子の 次元に general Procrustes 回転を実施した結 果, 得られた女子の次元と男子の次元間の coefficient of congruence を示したのが, 表 3 の右の列である。しかし，上で既に恋められた 弱い次元間の対応网係が若干明確になった程度 であり，新たな対応闍係はほとんど認められな い. また，非常に高い類似度を示した次元の組 合せす少ない，このような結果は，女子の次元 をターゲットとした場合です得られた。上記の 比較は各次元間の関連性を固定して行われてい るが，この条件を除いた場合に相互に非常に類 似した次元が認められる可能性る否定できな いそこで，男女の各次元を異性の空間に最小 二乗の意味で最す類似した位圂に設定すること を試みた。表 4 は，男女の各次元を示すべクト 
衰 4.重回㷌分析の結果

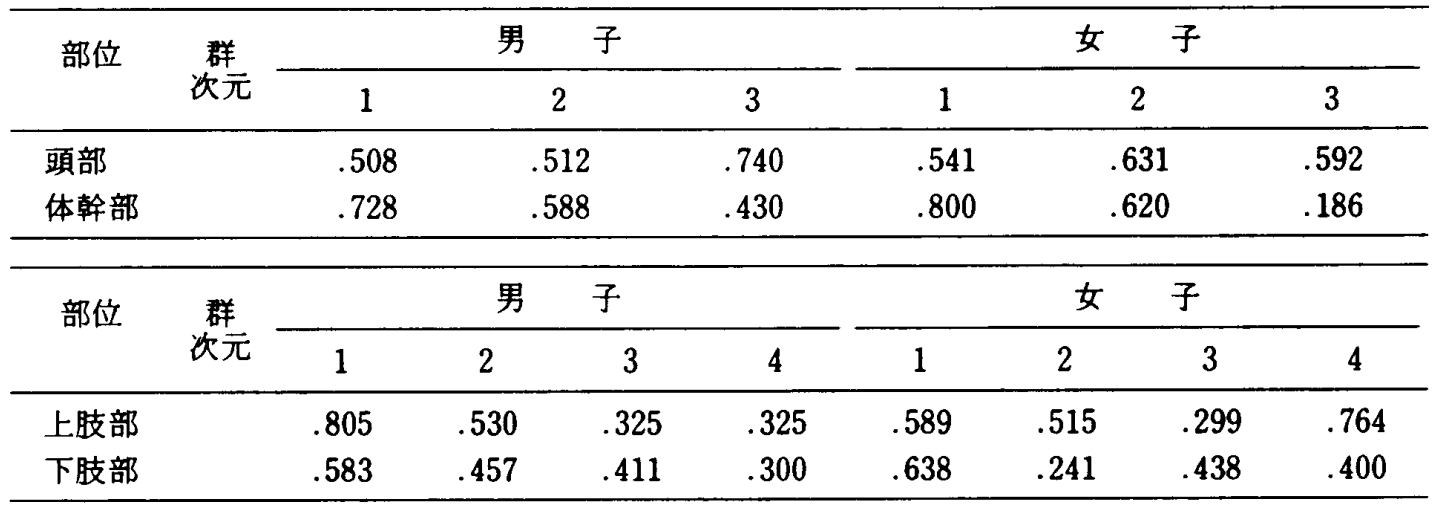

ルを異性の次元が張る空間に射影したべクトル と元のベクトル間の方向余弦を示している。こ れは (重) 相関係数に相当するので, 表 3 と比 較することが可能である，表を見ると，各次元 とも表 3 における最も類似している次元との coefficient of congruenceよりる若干高くなっ ている程度である。また，たとえば女子の頭部 の第 3 次元のように，このような楥い条件の下 においても非常に低い值を示す次元が認められ る.これらの次元は異性の空間において類似し た方向性がないことを示しており，明らかに固 有の次元であると言えよう。以上の結果は，男 女が全く同じ特性の次元を有しているのではな いことを示しているばかりでなく，共通である と考えられる次元が少なく，男女固有の次元も 互いに独立であるとは言い難いことす示唆して いる.したがって,WEM と男女別に SEM を䔔 合した場合の非適合度の差異を無視すべきでは なく，後者のモデルが適切であると判断した。 したがって，男女における次元数は類似してい るが質的に異なっている次元が多く，知識の㭗 造の性に関する一般性の仮説は棄却された。そ して，このことは，直接的には男女が全く同じ 特性から重要度を評価しているのではなく，少 なくともいくつかの異なった特性を用いて評価 していることを示唆している，したがって，知 識の体制化の特性は異なっていると推測され る.

次に，非類似性の尺度水準をデータ説明の精 度から検討するため，間隔・順序尺度のそれぞ
れを仮定し，男女別に SEM を商合した際の距 離（モデル）による非類似性（データ）の説明 率とその相関係数を表 5 に示した。身体部位や 性によって差異はあるが順序尺度を仮定した場 合の方が説明率で約 2-11\%とわずかに高い 值を示している。しかし，順序尺度を仮定した 場合にはディスパリティ（disparity，高根(1)） が潜在的な心的プロセスを反映した計量的デー タと考えることができるので，距離によるディ スパリティの説明率と比較すると約 16-30\% の差異が認められる，そこで，本研究ではこの 説明率の差異を重視し，以下，順序尺度の仮定 の下で解析を進めることにする。

以上の知見から，性別にMDSCALを適用 し，知識を棈造化している有意味な特性を見つ けるために得られた空間に Normal Varimax 基準による回転をした次元の解釈を示したのが 表 6 である。

各身体部位別に得られた次元の特性を見てみ ると,まず, 頭部に関する次元は, 男子では「顔・ 首の惄張度（顔・首の䋈張とリラックスを両亟 とする次元であり，以下（顔・首の惄張一リラッ クス)のように記す)」,「䝷の状態(影を出す一引 く)」,「首の運動(首の固定一張る)」，女子では 「䫫の状態（䪽を引く一口を開く）」，「首の㗨張 度」，「視線（視線の固定一動かす）」に成する特 性であると解积され，解粎の上では第 2 次元に 差異が認められ（カッコ内は，各次元の両極に 対応する内容を示している)。

上肢部に関する次元は，男子では「腕振りの 


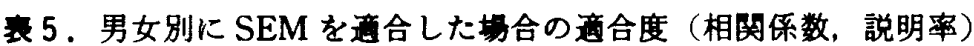

\begin{tabular}{|c|c|c|c|c|c|c|c|}
\hline \multirow{3}{*}{\multicolumn{2}{|c|}{$\begin{array}{c}\text { 尺度水淮 (手法) } \\
\text { 対象測度 } \\
\text { 部位 性 \指標 }\end{array}$}} & \multirow{2}{*}{\multicolumn{2}{|c|}{$\frac{\text { 間隔尺度 (COSCAL) }}{\text { 非類似性一距離 }}$}} & \multicolumn{4}{|c|}{ 順序尺度 (MDSCAL) } \\
\hline & & & & \multicolumn{2}{|c|}{ 非類似性一距離 } & \multicolumn{2}{|c|}{ ディスパリティー距蜼 } \\
\hline & & $\mathrm{r}^{11}$ & $r^{2} \times 100^{2)}$ & $r^{1)}$ & $\mathbf{r}^{2} \times 100^{21}$ & $\mathbf{r}^{1)}$ & $\mathrm{r}^{2} \times 100^{2)}$ \\
\hline \multirow[t]{2}{*}{ 頭部 } & 男子 & .740 & 54.7 & .800 & 64.0 & .922 & 85.0 \\
\hline & 女子 & .735 & 54.0 & .749 & 56.1 & .890 & 79.2 \\
\hline \multirow[t]{2}{*}{ 上肢部 } & 男子 & .728 & 53.0 & .800 & 64.0 & .894 & 79.9 \\
\hline & 女子 & .749 & 56.1 & .784 & 61.5 & .896 & 80.3 \\
\hline \multirow[t]{2}{*}{ 体幹部 } & 男子 & .838 & 70.2 & .860 & 74.0 & .935 & 87.4 \\
\hline & 女子 & .836 & 69.9 & .845 & 71.4 & .932 & 86.9 \\
\hline \multirow[t]{2}{*}{ 下肢部 } & 男子 & .796 & 63.4 & .831 & 69.1 & .910 & 82.8 \\
\hline & 女子 & .714 & 51.0 & .774 & 59.9 & .879 & 77.3 \\
\hline
\end{tabular}

1) Pearson の稳率相威係数

2) 説明率 (\%)

袁 6. 男・女において得られた次元の解釈

\begin{tabular}{|c|c|c|c|}
\hline 身体部位 & 次元 & 男 & 女 \\
\hline \multirow[t]{3}{*}{ 頭部 } & 1 & 顔・首の婪張度 & 頼の状態 \\
\hline & 2 & 頼の状態 & 首の慗張度 \\
\hline & 3 & 首の運動 & 視線 \\
\hline \multirow[t]{4}{*}{ 上肢部 } & 1 & 腕振りの大きさ & 腕の㗨張度 \\
\hline & 2 & 腕振りの譏能 & 时角の変化 \\
\hline & 3 & 脆振りの力強さ & 腕振りの樌極性 \\
\hline & 4 & 注意する部位 & 腕振りの大きさ \\
\hline \multirow[t]{3}{*}{ 体幹部 } & 1 & 姿慜 & 努繁 \\
\hline & 2 & 腰の動作 & 腰の動作 \\
\hline & 3 & 腰入れ & 体幹の框張度 \\
\hline \multirow[t]{4}{*}{ 下䁌部 } & 1 & 脚の回転の方向性 & 脚の回転の方向性 \\
\hline & 2 & 脚動作の強調点 (1) & \multirow{2}{*}{$\begin{array}{l}\text { 脚動作の強調点 (4) } \\
\text { 脚動作の強調点 (5) }\end{array}$} \\
\hline & 3 & 脚動作の強調点 (2) & \\
\hline & 4 & 脚動作の強調点 (3) & 強調する部位 \\
\hline
\end{tabular}

大きさ（大きい一小さい)」，「腕振りの機能 (リ ズムをとるたけ一体を押さえる)」「腕振りの力 強さ(リラックスした軽い振り一力強い振り)」, 「注意する部位 (肩一手)」，女子では「腕の緊張 度」,「肘角の变化(固定一变化)」,「脆振りの稓 極性（积極的一消極的）」，「腕振りの大きさ（大 きい一小さい)」と解积され，「脆振りの大きさ」 に闵する次元以外は解积上異なっていた。

体幹部に関する次元は，男子では「姿繁（前 傾一後傾)」,「腰の動作(腰の回転一固定)」,「腰
入れ（腰を入れる一腰を引く）」，女子では「努 愬（前傾する・腰を入れる一後傾する・腰を引 く）」,「腰の動作（腰の固定一回転）」,「体幹の 緊張度 (緊張一リラックス)」之解釉され，2つ の次元は類似していた。

下肢部に関する次元は，男子では「脚の回転 の方向性(まっすぐ一雪む)」,「脚動作の強調点 （1）(キック強調一大腿の引出し強調）」,「脚動 作の強調点 (2)（キック強調一脚の回転強調）」, 「脚動作の強調点(3)（キック強調一足の振り下 ろし強調)」，女子では「脚の回転の方向性(まっ すぐ一歪む)」,「脚動作の強調点(4)（キック強 調一大眼・憷の引き壮強調)」,「脚動作の強調 点 (5) （大眼・瞵の引出し強調一足の引き付け 強調)」, 「強調する部位（大腿一足）」と解釈さ れ，「脚の回転の方向性」に関する次元以外は解 釈上異なっていた。これらの特性は，短距離走 動作の専門家であると考えられる短距離走選手 が，短距離走の中間疾走局面の動作に関する知 識から抽出した情報の重要度を評価するために 用いている観点であるといら点で重要である。

以上のよ5に，短距離走の動作に関する知識 の構造は性によって異なっており，知識を構造 化している特性自体が異なっていること（質的 差異）が認められた。また，身体部位別に見た 場合，体幹部では次元の特性の性差が小さく， 
衰 7. 加速疾走局面において男・女で得られた次元の解积”

\begin{tabular}{|c|c|c|c|}
\hline 身体部位 & 次元 & 男 & 女 \\
\hline \multirow[t]{4}{*}{ 頭部 } & 1 & 顔の向き & 顔と首の㗨張度 \\
\hline & & 呼吸の有無 & 顔の上げ方 \\
\hline & 2 & 顔と視線の上げ方 & 視線の位嘈 \\
\hline & 3 & 顔面と首の緊張の程度 & 額の引き方 \\
\hline \multirow[t]{5}{*}{ 上肢部 } & 1 & 他の部位との関連性の有無 & 手の棸張の程度 \\
\hline & & & 咜振りの大きさ \\
\hline & 2 & 他の部位との関連の方向性 & 他の部位との网連の有無 \\
\hline & & 上肢の緊張の程度 & 上肢の㗨張の程度 \\
\hline & 3 & 局の緊張度 & 他の部位との軍の方向性 \\
\hline \multirow[t]{7}{*}{ 体幹部 } & 1 & 腰の高さ & 腹筋の㗨張の程度 \\
\hline & & 腰いれの程度 & 䁏の高さ \\
\hline & & 背の伸展 & \\
\hline & 2 & 前傾の程度 & 上体の前頋の程度 \\
\hline & & 腰の回転の有無 & 背の伸展 \\
\hline & & & 脚動作との関連の方向性 \\
\hline & 3 & 腹出しの有無 & 前への突っ込みの程度 \\
\hline \multirow[t]{7}{*}{ 下肢部 } & 1 & 脚の回転の万向性 & 強調点 (1) \\
\hline & & キック強調の程度 & \\
\hline & 2 & 下駺の振り出しの程度 & 下䡙の振出しの程度 \\
\hline & & キックアップの大きさ & \\
\hline & & 地面の捉え方 & \\
\hline & 3 & 大良の出し方 & 強調点 (2) \\
\hline & & 下稂の動かし方 & \\
\hline
\end{tabular}

1）稲垣はか23)より引用

頭部，上肢部，下肢部では性差が大きいことが 認められたが，特に，頭部において差異が大き いという結果は，これまでに報告した専門種目 差 (Inagaki and Matsuura ${ }^{16)}$, 稲垣・松浦 ${ }^{18}$, 稲垣浪 ${ }^{20)}$ ) p短距離走能力差（稲垣・松浦 ${ }^{199}$, 稲垣ほか22)）において認められた㑯向とは異 なっていた。

次に，構造の疾走局面に関する知識構造の一 般性を検討するため，上記の次元を加速疾走局 面における次元(稲垣はか ${ }^{23}$ ) $)$ と比較した。表 7 は，加速疾走局面における次元の解釈であり， 表 8 は両局面において共通な項目を用いて算出 した両局面の次元間の coefficient of congruence である. 表 8 に示されているよ5に, 男女 の上肢部を除いて中程度以上の値を示している 次元が 1 組ずつ認められる。しかし，解釈上類 似しているにすかかわらず値が低い次元の組合
せや反対に解釈上異なっているにるかかわらず 高い值を示している次元の組合せも認められ る.これは一つには coefficient of congruence の算出において両局面で共通した項目のみを用 いるので，次元の特性を解釈するために重要な 項目が除かれて計算されていることによると考 えられる。るら一つは，次元の解釈と次元間の 類似性を評価する観点が若干異なることによる と考えられる。つまり，次元の解釈は主として 坐標の絶対値が大きい項目を対象として行われ るが, coefficient of congruence は全ての項目 を対象とするからである。したがって，解积上 の内容から比較することも, coefficient of congruence で比較することも若干の問題が残る が，いずれの場合においてす質的に異なってい る次元が多いことが認められることから，垁走 局面に闺する知識の構造の一般性の仮説は萧却 


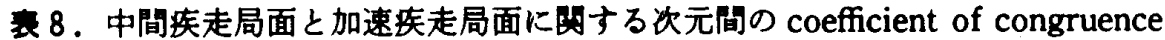

\begin{tabular}{|c|c|c|c|c|c|c|c|}
\hline \multirow{3}{*}{$\begin{array}{l}\text { 疾走 } \\
\text { 局面 } \\
\text { 中間 } \\
\text { 疾走 }\end{array}$} & \multicolumn{7}{|c|}{ 加速疾走 ${ }^{1)}$} \\
\hline & \multirow{2}{*}{ 性 } & \multicolumn{3}{|c|}{ 男 } & \multicolumn{3}{|c|}{ 女 } \\
\hline & & 1 & 2 & 1 & 1 & 2 & 1 \\
\hline \multirow[t]{3}{*}{ 頭部 } & 1 & -.089 & -.020 & .752 & -.219 & -.153 & .379 \\
\hline & 2 & .015 & .441 & .229 & .385 & -.771 & -.091 \\
\hline & 3 & -.369 & -.383 & .388 & -.063 & .303 & .108 \\
\hline \multirow[t]{4}{*}{ 上肢部 } & 1 & .068 & -.377 & .310 & -.116 & .343 & -.398 \\
\hline & 2 & .230 & -.101 & .062 & .377 & .421 & .121 \\
\hline & 3 & .138 & .158 & .149 & -.284 & .148 & -.018 \\
\hline & 4 & .297 & .036 & .270 & .276 & .154 & .164 \\
\hline \multirow[t]{3}{*}{ 体幹部 } & 1 & .496 & .172 & .089 & .596 & -.175 & -.016 \\
\hline & 2 & .048 & .083 & .228 & -.146 & .347 & .065 \\
\hline & 3 & -.410 & -.157 & .106 & -.068 & .164 & -.223 \\
\hline \multirow[t]{4}{*}{ 下肢部 } & 1 & -.646 & .166 & -.006 & .637 & -.360 & -.344 \\
\hline & 2 & .450 & .030 & .336 & .149 & .205 & -.236 \\
\hline & 3 & -.465 & .117 & -.056 & -.112 & .061 & -.072 \\
\hline & 4 & -.358 & .120 & .061 & -.514 & .130 & .355 \\
\hline
\end{tabular}

1）稲垣ほか23)で報告された次元（表 7 に対応）

すべきであろう。この結果は，直接的には短距 離走選手が加速疾走局面之中間疾走局面の動作 の重要度を異なった钼点から評価していること を示唆している。そして，この観点の差異は多 くの専門家が長年の短距離走トレーニングの経 検を通して蓄积し，評価し，取抬選択した後の 差異なので，有意味な情報が含まれている。

以上の結果は，短距離走動作に成する意識を 変容させることによって短距離走能力の向上を 目指す教示やメンタルブラクティスにおいて， 対象者の「性」や「疾走局面」を考虑する必要 性を暗示するるのであろう。

\section{2. 主解的直要度の模期}

表 9 は，少なくとも男・女いずれかにおいて， 主钼的重要度が 5.0 以上であった項目を示した ものである。各項目の重要度評価に用いた 7 段 階評定尺度の各カテゴリーに対応する重要度の 程度表現が,「全く重要でない」(1),「重要でな い」(2)，「余り重要でない」(3)，「どちらとす 言えない」(4),「やや重要である」（5），「重要 である」(6)，「非常に重要である」（7）であり， 標準㜊差が 1.0 前後であったことを考虚する
と，これらの項目は，重要度評価尺度の連続性 と分布の正規性の仮定の下で，標本となった専 門家の $80 \%$ 前後が肯定的に捉えている内容で ある。したがって，これらの項目は高い短距離 走能力と曹富な短距離走の程験を有する短距離 走選手に高い確率で支持されているといら点か ら,経験的に重要である内容であると言えよう。 さらに，表 9 の各項目を見ると，それぞれの内 容が陸上競技の指尊者が著した指学者において 肯定的に述べられている内容や，多くの指繤者 が指寘場面で選手に与える教示と類似している 内容が多いことがわかる、たとえば，「䫅が摇れ るぐらいリラックスする」(H 2),「頻を引く」 （H 7)，「手は軽く握る」(A 3)，「手は軽く握る」 (A 3)，「腕を前後に大きく振る」(A 22)，「腋を 締めて振る」(A 33),「力強く腕を振る」(A 44), 「肩をリラックスさせる」(A 47)，「上体を前傾 させる」（T 1)，「腹を締める」（T 12），「腰の位 目を高く保つ」（T 17），「腰を後ろに残さず乗せ ていく」(T 25),「一直線上を走る」(L 1)，「まっ すぐキックする」(L 37)，「㮏を高く上げる」 （L 55)，「憷を前に引き出す」(L 57)，「㮏をまっ 
衰 9.短距離走選手群における情数の主钼的重要度

\begin{tabular}{|c|c|c|c|c|c|c|}
\hline \multirow{2}{*}{ 部位 } & \multirow{2}{*}{ 項目番号 } & \multirow{2}{*}{ 内 } & 男 & \multirow{2}{*}{$\frac{\text { 子 }}{\text { S.D. }}$} & \multirow{2}{*}{$\frac{\text { 女 }}{\text { Mean }^{1)}}$} & \multirow{2}{*}{$\frac{\text { 子 }}{\text { S.D. }}$} \\
\hline & & & Mean $^{1)}$ & & & \\
\hline \multirow{3}{*}{ 頭部 } & $\mathrm{H} 2$ & 頓が描れるぐらいリラックスする & 5.49 & 1.45 & 4.15 & 1.52 \\
\hline & $\mathrm{H} 17$ & 顎を引く & 5.58 & 1.16 & 5.45 & 0.99 \\
\hline & $\mathrm{H} 20$ & 首をリラックスさせる & 5.20 & 1.58 & 4.28 & 1.48 \\
\hline \multirow[t]{7}{*}{ 上肢部 } & A3 & 手は辕く暒る & 5.19 & 1.54 & 5.31 & 1.22 \\
\hline & A22 & 腕を前後に大きく振る & 5.24 & 1.35 & 5.07 & 1.43 \\
\hline & A33 & 腋を締めて振る & 4.78 & 1.49 & 5.27 & 1.18 \\
\hline & A44 & 力強く腕を振る & 4.50 & 1.39 & 5.01 & 1.17 \\
\hline & A45 & できるたけ速く腕を振る & 4.96 & 1.46 & 5.35 & 1.27 \\
\hline & A46 & 腕をリラックスさせる & 6.30 & 1.06 & 5.57 & 1.34 \\
\hline & A47 & 屃をリラックスさせる & 6.24 & 1.10 & 5.86 & 1.13 \\
\hline \multirow[t]{6}{*}{ 体幹部 } & $\mathrm{T} 1$ & 上体を前傎させる & 5.24 & 1.34 & 5.23 & 1.10 \\
\hline & $\mathrm{T} 12$ & 腹を編める & 4.28 & 1.49 & 5.51 & 1.22 \\
\hline & $\mathrm{T} 17$ & 腰の位置を高く保つ & 6.27 & 1.11 & 6.17 & 1.01 \\
\hline & $\mathrm{T} 24$ & 殹を入れる & 5.23 & 1.58 & 5.27 & 1.47 \\
\hline & T25 & 腰を啳ろに残さず乗せていく & 5.39 & 1.58 & 6.10 & 1.07 \\
\hline & $\mathrm{T} 28$ & 埂を脚とともに引き出す & 4.69 & 1.47 & 5.34 & 1.24 \\
\hline \multirow[t]{17}{*}{ 下肢部 } & L1 & 一直線上を走る & 5.22 & 1.57 & 5.12 & 1.42 \\
\hline & L15 & 地面を足の衰でつかむ & 4.59 & 1.54 & 5.24 & 1.41 \\
\hline & L16 & 着地時間を短くする & 5.04 & 1.65 & 5.27 & 1.31 \\
\hline & L24 & 地面に押す様にキックする & 4.96 & 1.42 & 5.16 & 1.21 \\
\hline & L37 & まっすぐキックする & 5.25 & 1.26 & 5.22 & 1.19 \\
\hline & L41 & 足を大䭆に引き込むつもりで引きつける & 4.74 & 1.51 & 5.19 & 1.24 \\
\hline & L46 & 足は尻の外側に引き付ける & 5.59 & 1.13 & 3.13 & 1.05 \\
\hline & $\mathrm{L} 47$ & 足は尻にまっすぐ引き付ける & 4.84 & 1.38 & 5.04 & 1.26 \\
\hline & L55 & 㮏を高く上げる & 5.34 & 1.33 & 5.30 & 1.26 \\
\hline & L57 & 滕を前に引き出す & 5.11 & 1.44 & 5.42 & 1.04 \\
\hline & L60 & 膝をまっすぐ引き出す & 4.99 & 1.35 & 5.00 & 1.14 \\
\hline & L65 & 腰の動きが脚を引き出す & 4.81 & 1.38 & 5.07 & 1.30 \\
\hline & L71 & 椩を柔らかく使ら & 5.62 & 1.44 & 5.54 & 1.09 \\
\hline & L84 & 股を大きく閁く & 5.10 & 1.37 & 4.54 & 1.51 \\
\hline & L85 & ストライドを広くして走る & 5.41 & 1.27 & 5.23 & 1.42 \\
\hline & L86 & ピッチの速さを強調する & 5.36 & 1.35 & 5.77 & 1.12 \\
\hline & L88 & 脚の回伝を強調する & 4.82 & 1.50 & 5.22 & 1.25 \\
\hline
\end{tabular}

1) 主钼的重要度

すぐ引き出す」(L 60)，「股を大きく開く」(L 84) などである。このよ5に，本研究で設定された 主観的重要度は，専門家としてコ一チの経険的 知識 む十分に反映していると考えられることか ら，「経検的重要度」と一般化することが可能で あろう。

次に，主観的重要度の性に咸する一般性を検 討するため，ここで得られた主観的重要度にお
ける性差の有無を $\mathrm{t}$ 検定により検討した，表 10 と表 11 は，それぞれ男子，および女子における 主钼的重要度が他方上り有意に高いことが認め られ項目を示している．表に示されているよら に，いずれの身体部位においても有意な性差が 認められた項目が多いことから，主钼的重要度 の被検者の性に関する一般性の仮説は衰却すべ きであろう。 
言10，男子における主兒的重要度が女子より有意に高い項目（ $\mathrm{p}<0.05 ）$

\begin{tabular}{|c|c|c|c|c|c|c|}
\hline \multirow{2}{*}{ 部位 } & \multirow{2}{*}{ 項目番号 } & \multirow{2}{*}{ 内 } & 男 & 子 & 女 & 子 \\
\hline & & & Mean" & S.D. & Mean') & S.D. \\
\hline \multirow[t]{5}{*}{ 頭部 } & $\mathrm{H} 2$ & 煩が括れるぐらいリラックスする & 5.49 & 1.45 & 4.15 & 1.52 \\
\hline & H3 & 笑い顔で走る & 3.34 & 1.66 & 1.93 & 1.10 \\
\hline & $\mathrm{H} 20$ & 首をリラックスさせる & 5.20 & 1.58 & 4.28 & 1.48 \\
\hline & H32 & シューシュー等と言いながら走る & 2.87 & 1.43 & 2.42 & 1.40 \\
\hline & H33 & ロの中で歌を歌いながら走る & 2.33 & 1.20 & 1.94 & 1.14 \\
\hline \multirow[t]{13}{*}{ 上肢部 } & A4 & 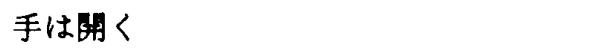 & 4.21 & 1.34 & 3.53 & 1.41 \\
\hline & A9 & 腕を後ろに振った時に手を後方に反らせる & 3.32 & 1.14 & 2.82 & 1.31 \\
\hline & A14 & 腕が体側を通る時に肘を伸ばす & 3.17 & 1.49 & 2.49 & 1.25 \\
\hline & A15 & 时の角度を前で小さくする & 4.00 & 1.40 & 3.45 & 1.28 \\
\hline & A16 & 肘の角度を後ろで大きくする & 4.04 & 1.45 & 3.35 & 1.32 \\
\hline & A34 & 腕は前で内側に入る & 4.04 & 1.39 & 3.61 & 1.42 \\
\hline & A36 & 腕は後ろで内側にはいる & 2.89 & 1.32 & 2.46 & 1.07 \\
\hline & A39 & 腕は下の方で振る & 4.03 & 1.67 & 3.52 & 1.32 \\
\hline & A46 & 腕をリラックスさせる & 6.30 & 1.06 & 5.57 & 1.34 \\
\hline & A47 & 局をリラックスさせる & 6.24 & 1.10 & 5.86 & 1.13 \\
\hline & A52 & 有を上下動させる & 2.64 & 1.20 & 2.23 & 1.12 \\
\hline & A58 & 脆振りで体が浮かない様に押さえる & 4.22 & 1.20 & 3.83 & 1.28 \\
\hline & A60 & 腕振りで䐘を回転させる & 4.92 & 1.52 & 4.26 & 1.52 \\
\hline \multirow[t]{3}{*}{ 体幹部 } & $\mathrm{T} 14$ & 腹をリラックスさせる & 4.05 & 1.40 & 2.82 & 1.35 \\
\hline & $\mathrm{T} 16$ & 背中をリラックスさせる & 4.50 & 1.33 & 3.60 & 1.16 \\
\hline & $\mathrm{T} 22$ & 尻を後ろに出す & 2.72 & 1.24 & 2.30 & 1.11 \\
\hline \multirow[t]{12}{*}{ 下肢部 } & L10 & 足の愛の外側で地面を捉える & 4.18 & 1.34 & 3.72 & 1.29 \\
\hline & L19 & 伸ばして着地する & 4.25 & 1.46 & 3.43 & 1.41 \\
\hline & L31 & 足の辰の外側に重心がかかる & 3.99 & 1.40 & 3.53 & 1.21 \\
\hline & L46 & 足は尻の外側に引き付ける & 5.59 & 1.13 & 3.13 & 1.05 \\
\hline & L58 & 㮏を内側に引き出す & 3.95 & 1.26 & 3.31 & 1.07 \\
\hline & L75 & 足は内側に振り下ろす & 3.47 & 0.96 & 2.94 & 1.21 \\
\hline & L77 & 足は外側に振り下ろす & 3.23 & 1.01 & 2.85 & 1.19 \\
\hline & L79 & かかとを振り下ろす & 3.99 & 1.35 & 3.39 & 1.35 \\
\hline & L80 & 足首で地面をひっかく & 4.41 & 1.36 & 3.90 & 1.37 \\
\hline & L82 & 足を地面にたたきつける & 4.10 & 1.45 & 3.50 & 1.54 \\
\hline & L83 & 着地する時に足首の力を抜く & 4.10 & 1.43 & 3.63 & 1.47 \\
\hline & L84 & 股を大きく開く & 5.10 & 1.37 & 4.54 & 1.51 \\
\hline
\end{tabular}

1）主覞的重要度

このよらに性差が認められたことから，実用 化のためにより詳細な性差に関する情報を提供 するために，各身体部位ごとに性差を検討する ことにする。

まず，頭部で有意差が認められたのが，H 14 を除いて「顔面と頚部の緊張度」に威する項目 であることがわかる。 そして，男女とも顔面と 頝部のリラックスに対して肯定的であるが，男
子の方が相対的によりリラックスすることを肯 定していることが認められる。

上肢部に関しては，主として「上肢の緊張度」 と「肘角の変化」に成する内容で差異があるこ とがわかる，上肢の緊張度に咸しては，男女と るリラックスさせることに対して肯定的である が，男子の方がより肯定的であることが認めら れる(A 2, A 4, A 5, A 9, A 46, A 47). 肘角 
言11.女子における主钼的重要度が男子より有意に高い項目（p<0.05）

\begin{tabular}{|c|c|c|c|c|c|c|}
\hline \multirow{2}{*}{ 部位 } & \multirow{2}{*}{ 項目番号 } & \multirow{2}{*}{ 内 } & 男 & \multirow{2}{*}{$\frac{\text { 子 }}{\text { S.D. }}$} & \multirow{2}{*}{$\frac{\text { 女 }}{\text { Mean }^{1)}}$} & \multirow{2}{*}{$\frac{\text { 子 }}{\text { S.D. }}$} \\
\hline & & & Mean $^{1)}$ & & & \\
\hline \multirow[t]{3}{*}{ 頭部 } & $\mathrm{H} 4$ & 粕をくいしばる & 2.45 & 1.43 & 2.94 & 1.37 \\
\hline & $\mathrm{H} 14$ & 決勝テープを見る & 3.75 & 1.56 & 4.21 & 1.35 \\
\hline & $\mathrm{H} 19$ & 首に力を入れる & 2.00 & 0.99 & 2.55 & 1.38 \\
\hline \multirow[t]{6}{*}{ 上肢部 } & $\mathrm{A} 2$ & 手はぎゅっと握りしめる & 2.00 & 1.08 & 2.67 & 1.36 \\
\hline & A5 & 手首を固定する & 3.15 & 1.28 & 3.57 & 1.39 \\
\hline & A10 & 时の角度を固定する & 3.83 & 1.41 & 4.65 & 1.14 \\
\hline & A 12 & 肘の角度を 90 度にする & 3.95 & 1.28 & 4.41 & 1.32 \\
\hline & A33 & 腋を締めて振る & 4.78 & 1.49 & 5.27 & 1.18 \\
\hline & A44 & 力強く腕を振る & 4.50 & 1.39 & 5.01 & 1.17 \\
\hline \multirow[t]{5}{*}{ 体幹部 } & T12 & 腹を締める & 4.28 & 1.49 & 5.51 & 1.22 \\
\hline & $\mathrm{T} 15$ & 背筋に力を入れる & 3.43 & 1.16 & 3.87 & 1.30 \\
\hline & $\mathrm{T} 25$ & 腰を後ろに牫さず乗せていく & 5.39 & 1.58 & 6.10 & 1.07 \\
\hline & $\mathrm{T} 26$ & 腰を伸ばしながらキックする & 4.22 & 1.25 & 4.65 & 1.43 \\
\hline & $\mathrm{T} 28$ & 腰を脚とともに引き出す & 4.69 & 1.47 & 5.34 & 1.24 \\
\hline \multirow[t]{7}{*}{ 下肢部 } & L4 & かかとを着かない様に走る & 3.62 & 1.60 & 4.12 & 1.54 \\
\hline & L6 & 重心の前方で地面を捉える & 3.82 & 1.52 & 4.58 & 1.46 \\
\hline & L15 & 地面を足の夏でつかむ & 4.59 & 1.54 & 5.24 & 1.41 \\
\hline & L18 & 㮏を縟めて着地する & 3.47 & 1.44 & 4.10 & 1.50 \\
\hline & L20 & 膝を曲げてためてからキックする & 3.80 & 1.34 & 4.83 & 1.28 \\
\hline & $\mathrm{L} 41$ & 足を大駺に引き込むつもりで引き付ける & 4.74 & 1.51 & 5.19 & 1.24 \\
\hline & L86 & ピッチの速さを強調する & 5.36 & 1.35 & 5.77 & 1.12 \\
\hline
\end{tabular}

1）主钼的重要度

の変化に関しては，男子は中性的な評価である が，女子は固定することに対して肯定的である (A 10, A 12, A 14, A 15, A 16). その他, 男 子が腕振りで腰を回転させること」(A 60)を， 女子が「腋を締めること」(A 33）と「力強く腕 を振ること」(A 44)をより肯定的に捉えている ことなどが認められる。

体幹部に関しては，「体幹部の棸張度」と「腰 の前後方向における動作」に成する内容で差異 があることがわかる.体幹の婜張度に対しては, 男子は中性的な評価であるのに対し，女子では 背筋に関しては不明確であるが(T 15)，腹筋の 㗨張に対しては肯定的であることが認められる (T 12).腰の前後方向における動作に成して は，男女とも腰を前に出すことに対して肯定的 であるが，女子の方がより肯定的であることが わかる（T 22, T 25, T 26, T 28).

下肢部に関しては，主として「脚動作の方向
性」と「着地の仕方」に阅する内容で差異が認 められる。「脚動作の方向性」に関しては，男子 が足を尻の外側に引き付けることに肯定的であ るのに対し，女子は否定的である(L 46). また， 脚を内・外方向に引き出したり振り下ろしたり することに関しては男女とも否定的であるが， 女子の方がより否定的である（L 58，L 75， L 77).「着地の仕方」に咸しては，男子は㮏を伸 ばして着地することに肯定的であるが，女子は 膝を释めて着地することに対して肯定的である ことがわかる（L 18，L 19)。 また，足を振り戻 すような積極的な着地に対しては，男子が中性 的評価であるのに対し，女子は否定的である （L 6，L 79，L 80，L 82）。その他，男子は股を 大きく開くことに対してょり肯定的であり （L 84），女子はピッチの速さを強調することに 対してより肯定的であることが認められる (L 86). 


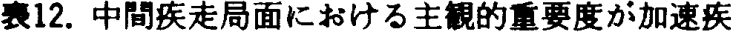
走局面上り有意に高い項目（ $\mathrm{p}<0.05 ）$

\begin{tabular}{|c|c|c|c|}
\hline $\begin{array}{l}\text { 項目 } \\
\text { 番号1 }\end{array}$ & 内 & 中間2) & 加速3) \\
\hline $\mathrm{H} 13$ & 隣の遭手を見る & 2.74 & 1.90 \\
\hline $\mathrm{H} 17$ & 䫔を引く & 5.51 & 4.74 \\
\hline A16 & 时の角度を後ろで大きくする & 3.65 & 2.51 \\
\hline $\mathrm{A} 23$ & コンパクトに腕を振る & 4.17 & 2.74 \\
\hline A46 & 腕をリラックスさせる & 5.87 & 5.42 \\
\hline A60 & 腕振りで腰を回転させる & 4.55 & 3.97 \\
\hline $\mathrm{T} 17$ & 腰の位酎を高く保つ & 6.19 & 5.64 \\
\hline $\mathrm{T} 18$ & 聂を固定する & 4.29 & 3.67 \\
\hline $\mathrm{T} 19$ & 跃を左右に振る & 3.28 & 2.65 \\
\hline $\mathrm{Ll}$ & 一直線上を走る & 5.20 & 4.44 \\
\hline L43 & $\begin{array}{c}\text { かかうが杘にかすめる様に脚 } \\
\text { を引き付ける }\end{array}$ & 4.64 & 3.78 \\
\hline L55 & 滕を高く上け゚る & 5.29 & 4.87 \\
\hline L84 & 股を大きく開く & 4.78 & 4.07 \\
\hline L85 & ストライドを広くして走る & 5.35 & 4.65 \\
\hline
\end{tabular}

1）中間疾走局面における項目番号

2）中間智走局面における主観的重要度

3）加速疾走局面における主钼的重要度

このよ5に身体部位別の比較をして特徴的な のは，下肢部を除いて男子の方が一貫してリ ラックスすることをより肯定的に評価している ことである。この傾向は，短距離走が瞬発的な 能力を必要とする運動であることを考えると， 女子自身が相対的に瞬発力が不足していること を自覚しており，より力強い走りを指向してい ることを反映した結果ではないかと推測され る。

次に，各項目の主観的重要度の疾走局面間の 差異を検討するため，稲垣ほか23ににおいて得ら れた加速疾走局面に的する主観的重要度と比教 した。但し，中間疾走局面と加速疾走局面にお いて得られた項目が異なっていることから，二 局面で共通な 101 項目を用いた。

まず，各局面における主钼的重要度間の相成 保数を算出した結果，0.877 とかなり高い值で あったことから，両局面で共通した項目の主钼 的重要度は全体的には類似している傾向がある と言えよ5。そこで，次に，二局面における差 異をより具体的に検討するため，個々の項目の
主観的重要度の羑異を検討した。

表 12 は， $\mathrm{t}$ 検定の結果，中間疾走局面に沏け る主観的重要度が加速疾走局面においてょり有 意に高いことが認められた項目を示している。 この中で,「コンパクトに腕を振る」,「腕振りで 腰を回転させる」,「腰を固定する」,「かかとが 尻にかすめるよ5に脚を引き付ける」は中間疾 走局面では值が 4.0 以上であり，加速疾走局面 では 4.0 末満である. 本研究で用いられた 7 段 階評定尺度では中性的カテゴリーが 4.0 に対応 することを考慮すると，これらの項目は，両局 面でその重要度が大きく異なる項目であると言 える。この結果は，スタートから加速疾走局面 においては中間疾走局面よりも脚の動作が往復 運動に近く，低い位圈を足が通通すること （L 43）や，より強い腕振りによる反作用を用い て強いキックをし，また，ピッチを高める必要 がある（A 23，A 60）といら実際の動作から理 解できよ5。地の項目においてす，たと えば，加速疾走局面で顥を引く（H 13）ことは 上体を浮かせてしまらことから好ましくなく， 时を後ろで伸ばす（A 16）こと，股を大きく開 くこと(L 84)，ストライドを広くして走ること （L 85）は，加速疾走局面で重要なビッチを低下 させるため好ましくないと考えられる。また， 腰の位置を高くすること（T 17）は，体が浮い てキックを充分にできなくなり，膝を高く上げ ること（L 55)は，下方向へのキックが中間疾走 局面で相対的に大きく，加速疾走局面では後方 へのキックが大きくなるといら動作を反映して いると考えられる。

表 13 は, 反対に $\mathrm{t}$ 検定の結果, 加速疾走局面 における主钼的重要度が中間疾走局面において より有意に高いことが認められた項目を示して いる.この中で,「口を開く」,「肩を下に引っ張っ て下げる」，「腰を前に突き出す」，「足を地面に 突き出す」の項目は加速疾走局面では値が 4.0 以上であり,中間疾走局面では 4.0 末満である. これらの項目は，両局面でその重要度が大きく 異なる項目であると言える。この結果は，加速 疾走局面では，キックに腕振りの反作用を用い 
衰13. 加速疾走局面に括ける主锶的重要度が中間疾 走局面上り有意に高い項目（ $\mathrm{p}<0.05 ）$

\begin{tabular}{|c|c|c|c|}
\hline $\begin{array}{l}\text { 項目 } \\
\text { 番号1) }\end{array}$ & 内 & 中間2) & 加速 ${ }^{3)}$ \\
\hline H5 & ロを開く & 3.55 & 4.19 \\
\hline $\mathrm{H} 19$ & 首に力を入れる & 2.28 & 3.01 \\
\hline A41 & 腕は後ろの方で振る & 3.54 & 4.01 \\
\hline A48 & 屃を下に引っ張って下げる & 3.32 & 4.30 \\
\hline A49 & 局を固定して振らない & 3.40 & 4.00 \\
\hline A61 & 腕振りで体を引っ張る & 4.45 & 4.86 \\
\hline A62 & 腕振りで脚を引っ張る & 4.79 & 5.35 \\
\hline T5 & 背中を丸める & 2.59 & 2.95 \\
\hline $\mathrm{T} 12$ & 腹を締める & 4.97 & 5.32 \\
\hline $\mathrm{T} 13$ & 腹を出す & 2.32 & 2.69 \\
\hline $\mathrm{T} 23$ & 腰を前に突き出す & 3.67 & 4.25 \\
\hline L16 & 着地時間を短かくする & 5.15 & 5.81 \\
\hline L48 & 下眼はキック後,高く践り上げる & 3.56 & 3.94 \\
\hline L80 & 足首で地面をひっかく & 4.13 & 5.04 \\
\hline L82 & 足を地面にたたきつける & 3.72 & 4.23 \\
\hline
\end{tabular}

1）中間疾走局面における項目番号

2）中間疾走局面における主涀的重要度

3）加速疾走局面における主钼的重要度

るため，また，体を浮かさないためにる局を下 げること（A 48）は好ましく，後方にキックす るためにも腰を前に出すこと（T 23）は好まし いと考えられる．また，地面に足をたたきつけ ること(L 82)は，ピッチを高め，着地時の地面 の反作用を用いるためにも好ましいと考えられ る。また，他の項目です，加速疾走局面では大 きな力がかかることから身体は緊張気味になり （H 19），腕振りの反動を用いる（A 61，A 62） 必要があると考えられる。また，ピッチを速く するため，肩は振らず(A 49)，着地時間は短く する（L 16）必要があるからと考えられる。

以上に示したように，主観的重要度は加速疾 走局面と中間疾走局面では，全体的に大きな早 的差異はないと言えよう。しかし，個々の項目 を見ると大きく異なっている項目す認められ た。ささに，この結果が両局面において共通し て得られた 101 項目において認められた結果で あるといらことに注意すべきである。すなわち， 抽出された項目が大きく異なっていることは， 抽出されなかった局面ではその項目が重要でな
いと考えられていることを暗示している．した がって，動作に関する主観的重要度の各項目の 重要度は戦密な意味で疾走局面に関して一般的 であるとは言えなかろう。

以上のよらに，主観的重要度の「性」や「疾 走局面」に関する一般性は棄却された。このこ とは，短距離走選手が性によって，あるいは疾 走局面によって異なった「動作に関する意識」 をるっていることを暗示している。そして，こ の差異が多くの専門家が長年の短距離走トレー ニングの释験を通して蓄積し，評価し，取搭選 択した後の知識において生じた差異なので，そ の意味するすのは大きい，したがって，この差 異は男子と女子，加速疾走局面と中間疾走局面 で異なった「動作に関する意識」(意識上の目標) をあつべきであることを暗示するすのであろ 5 .

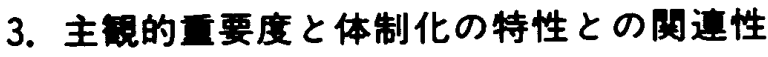 の検砷}

1.と2. で示したよ5に，知識構造と主観的 重要度の両方で性を認められたことから，両者 の関連性についての検討も男女別に行われた。

表 14 は，性，身体部位別に得られた座標行列 に, 主観的重要度を従属変数, 各体制化の特性 を独立変数とした重回㷌分析を適用した結果を 示したすのである。これらの表に示されている ように, 重相関係数は $0.847-0.958$ と非常に高 く，本研究で得られた体制化の特性によって主 観的重要度の分散の 71.7-91.7\%を説明でき ることを示している。このよ5に線形関数とい ら極めて条件の放しいモデルに対して高い適合 度を示したことから，各項目の主観的重要度が これらの体制化の特性の線形関数によって決定 されるといら構造を持つといら仮説は妥当であ ると考えられる。そして，このことは，同時に 得られた体制化の特性が主観的重要度を決定す る特性(要素)，すなわち下位尺度であることを 示している.

そこで，次に，各身体部位ごとに主観的重要 度に対する体制化の特性の関連の程度と肯定的 に捉えられている方向性（内容）を検討するこ 
表14. 重回㷌分析の結果

\begin{tabular}{|c|c|c|c|c|c|c|c|c|}
\hline 部位 & 性 & 次元 & 次元の解釈 & $\mathrm{b}$ 係数 & $\beta$ 係数 & $r^{1)}$ & 貢献度 ${ }^{2)}$ & 角度 ${ }^{3)}$ \\
\hline \multirow[t]{8}{*}{ 頭部 } & 男子 & 1 & 顔・首の叕張度 & -1.012 & -.645 & -.749 & 48.3 & 143.2 \\
\hline & & 2 & 額の状態 & .454 & .230 & .329 & 7.6 & 73.4 \\
\hline & & 3 & 首の運動 & -.790 & -.424 & -.581 & 24.6 & 121.8 \\
\hline & & \multicolumn{2}{|c|}{ 重相闺係数/説明率 } & & & .879 & 80.5 & \\
\hline & 女子 & 1 & 影状態 & -.854 & -.515 & -.602 & 31.0 & 48.6 \\
\hline & & 2 & 首の緊張度 & -.699 & -.414 & -.501 & 20.7 & 122.1 \\
\hline & & 3 & 視線 & .709 & .412 & .513 & 21.1 & 58.1 \\
\hline & & \multicolumn{2}{|c|}{ 重相閔係数/説明率 } & & & .854 & 73.0 & \\
\hline \multirow[t]{10}{*}{ 上肢部 } & 男子 & 1 & 腕振りの大きさ & -1.292 & -.841 & -.851 & 71.6 & 169.5 \\
\hline & & 2 & 腙振りの機能 & -.216 & -.121 & -.130 & 1.5 & 98.1 \\
\hline & & 3 & 脆振りの力強さ & -.060 & -.033 & -.041 & .1 & 92.2 \\
\hline & & 4 & 这意する部位 & -.170 & -.092 & -.158 & 1.5 & 96.2 \\
\hline & & \multicolumn{2}{|c|}{ 重相同係数/説明率 } & & & .864 & 74.9 & \\
\hline & 女子 & 1 & 腕の㗨張度 & .505 & .289 & .426 & 12.3 & 67.6 \\
\hline & & 2 & 肘角の変化 & .786 & .434 & .604 & 26.2 & 55.1 \\
\hline & & 3 & 腕振りの磧極性 & -.626 & -.031 & -.053 & .2 & 92.3 \\
\hline & & 4 & 腕振りの大きさ & .974 & .549 & .695 & 38.2 & 43.6 \\
\hline & & \multicolumn{2}{|c|}{ 重相成係数/説明率 } & & & .877 & 76.9 & \\
\hline \multirow[t]{8}{*}{ 体幹部 } & 男子 & 1 & 姿勢 & 1.166 & .847 & .859 & 72.8 & 15.8 \\
\hline & & 2 & 腰の動作 & .157 & .094 & .037 & .3 & 83.9 \\
\hline & & 3 & 腰入れ & -.350 & -.220 & -.265 & 5.8 & 104.5 \\
\hline & & \multicolumn{2}{|c|}{ 重相閔係数/説明率 } & & & .888 & 78.9 & \\
\hline & 女子 & 1 & 姿等 & -1.487 & -.925 & -.950 & 87.9 & 172.1 \\
\hline & & 2 & 掼の動作 & .123 & .069 & .253 & 1.7 & 85.8 \\
\hline & & 3 & 体幹の棸張度 & .231 & .109 & .186 & 2.0 & 83.3 \\
\hline & & \multicolumn{2}{|c|}{ 重相関係数/説明率 } & & & .958 & 91.7 & \\
\hline \multirow[t]{10}{*}{ 下肢部 } & 男子 & 1 & 回転の方向性 & -.774 & -.631 & -.705 & 44.5 & 144.1 \\
\hline & & 2 & 強調点 (1) & .299 & .232 & .270 & 6.3 & 72.7 \\
\hline & & 3 & 強調点 (2) & -.367 & -.281 & -.327 & 9.2 & 111.1 \\
\hline & & 4 & 強調点 (3) & -.345 & -.275 & -.429 & 11.8 & 110.7 \\
\hline & & \multicolumn{2}{|c|}{ 重相成係数/説明率 } & & & .847 & 71.7 & \\
\hline & 女子 & 1 & 回転の方向性 & .944 & .788 & .846 & 66.7 & 16.9 \\
\hline & & 2 & 強調点 (4) & -.005 & -.003 & -.029 & .0 & 90.2 \\
\hline & & 3 & 強調点(5) & -.099 & -.065 & -.130 & .8 & 94.5 \\
\hline & & 4 & 強調する 部位 & -.338 & -.230 & -.415 & 9.5 & 106.2 \\
\hline & & \multicolumn{2}{|c|}{ 重相凮倸数/説明率 } & & & .877 & 77.0 & \\
\hline
\end{tabular}

1）主筧的重要度と各次元の相開係数

2) 単位: \%

3）主钼的重要度べクトルの情報空間への射影と各次元のなす角度（単位：deg.）

とにする.

まず，頭部に関しては，男子では第 1 次元
（「顔・首の緊張度」）が著しく高い貢献度を有し ている，女子では第 1 次元（「顎の状態」）が高 
い貢献度を示しているが，他の次元との差異は 男子において認められるほど大きくはない，し たがって，男子では「顔・首の緊弾度」，女子で は「顎の状態」の特性が主観的重要度を評価す るに当たって最も高いウェイトを与えられてい ることを示しており，明確な性差があると言え よ5. 各次元の主観的に重要な方向を見ると， 男子において主観的に重要な方向は「顔・首の リラックス」(第 1 次元)，「類を引く」（第 2 次 元)，「首の固定」（第 3 次元）である．また，女

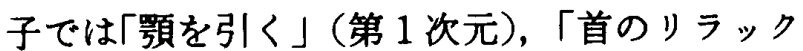
ス」(第 2 次元)，「視線の固定」（第 3 次元）で ある。このように，両性に扣いて「首のリラッ クス」，「䝷を引く」といら方向が主観的に重要 な方向であることが共通に認められた。

上肢部に関しては，男子では第 1 次元(「腕振 クの大きさ」）が著しく高い貢献度を有してお ク，他の特性は全く関与していないと言っても よかろ5．しかし，女子では第 4 次元(「腕振り の大きさ」) と第 2 次元 (「时角の変化」) の 2 つ の特性が高い貢献度を示しており，他の次元と の差異は男子において認められるはど大きくは ない。したがって，男子においては「腕振りの 大きさ」の特性，女子では「腕振りの大きさ」, 「肘角の変化」の特性が主観的重要度を評価する 上で最も高いウェイトをもっていることを示し ており，「腕振りの大きさ」の特性が重視されて いる点は共通していると言えよ5．各次元の主 観的に重要な方向を見ると，男子において主観 的に重要な方向は「前後に大きな腕振り」（第 1 次元)，「腕振りで体を押える」(第 2 次元)，（力 強い腕振り」(第 3 次元),「眉の動きに注意する」 （第 4 次元)であるが，上述したよ5に第 $2 ， 3$ ， 4 次元の方向性は不明確である.女子では「脆 のリラックス」（第 1 次元），「肘角の固定」（第 2 次元)，「積極的な腕振り」(第 3 次元），「小さ な腕振り」(第 4 次元)であるが，第 3 次元はは とんど㒺与していない。このように，特に男子 は大きな腕振りを重視し，女子は小さな腕振り を重視するというように，著しい性差が認めら れた。
体幹部に関しては，男女とも第 1 次元（「姿 勢」)が著しく高い貢献度を示している。このこ とは，いずれも「姿勢」の特性が主観的重要度 をほとんど決定することを示している．各次元 の主観的に重要な方向を見ると，まず，男子に おいて主観的に重要な方向は，「前傾」（第 1 次 元),「腰の固定」(第 2 次元)，「腰を入れる」(第 3 次元）であるが，上記のように第 1 次元以外 の方向性は不明確である。 また，女子では「前 傾」(第 1 次元)，「腰の回転」(第 2 次元)，「体 幹の緊張」(第 3 次元)であるが，男子と同様に 第 1 次元以外は不明確である。このように，男 女ともに「前傾」とい51つの特性を極端に重 視していることが認められた。しかし，男子は 「腰の固定」を，女子は「腰の回転」を重視して いるという点で反対であるが，関与の程度が極 端に小さいので特に強調すべき差異ではないと 考えられる。

最後に，下肢部に関しては，男女とも第 1 次 元（「脚の回転の方向性」）が著しく高い貢献度 を示している.したがって，下肢に関しては男 女とも「脚の回転の方向性」の特性が主観的重 要度をほとんど決定すると言ってすよく，性差 は認められなかった．各次元の主観的に重要な 方向を見ると，まず男子では，「まっすぐな脚の 回転」(第 1 次元),「大眼の引出しを強調」（第 2 次元),「脚の回転を強調」(第 3 次元),「脚の 振り下ろしの強調」(第 4 次元)であるが，上述 したよ5に第 1 次元以外は万向性が不明確であ る。また，女子では「まっすぐな脚の回転」（第 1 次元),「大脚・憷の引き上げ強調」(第 2 次元), 「大卧・瞵の引出し強調」(第 3 次元)，「足の動 きを注意」(第 4 次元)であるが，第 1 次元以外 は方向性が不明確である。このように，男女と も「まっすぐな脚の回転」といら方向が好まし いことが共通に認められた。 なお，表 15 に各次 元の主観的に重要な万向をまとめた。

このよらに，各特性が各項目の主観的重要度 の決定に関与している程度は，身体部位によっ ては性差が認められたが，その関与の方向性に は上肢部を除いて大きな差異は認められなかっ 
衰15，体制化の特性の主锐的に重要な方向性

\begin{tabular}{|c|c|c|c|}
\hline 部位 & 次元 & 子 & 女 \\
\hline \multirow[t]{3}{*}{ 頭部 } & 1 & 顔・首のリラックス & 頶を引く \\
\hline & 2 & 顠を引く & 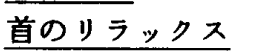 \\
\hline & 3 & 首の固定 & 視線の固定 \\
\hline \multirow[t]{4}{*}{ 上肢部 } & 1 & 前後に大きな腕振り & \multirow{2}{*}{$\begin{array}{l}\text { 腕のリラックス } \\
\text { 肘角の固定 }\end{array}$} \\
\hline & 2 & 腕振りで体を押さえる & \\
\hline & 3 & 力強い腕振り & 程票的な腕振り \\
\hline & 4 & 眉の動きに注意する & 小さな腕振り \\
\hline \multirow[t]{3}{*}{ 体幹部 } & 1 & 前傾 & 前傾 \\
\hline & 2 & 腰の固定 & 腰の回枟 \\
\hline & 3 & 掼入れ & 慗張 \\
\hline \multirow[t]{4}{*}{ 下肢部 } & 1 & まっすくなな脚の回転 & まっすぐな脚の回㫢 \\
\hline & 2 & 大辟の引出しを強調 & 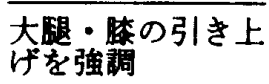 \\
\hline & 3 & 脚の回転を強調 & 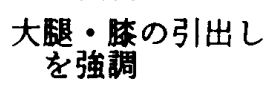 \\
\hline & 4 & 脚の振り下ろしを強調 & 足の動きに注意 \\
\hline
\end{tabular}

注）アンダーラインは特に関与の程度が高く，方 向性が明碓な特性を示す

た。したがって，主観的重要度を決定するのに 重視される特性は男女間で異なっているが，共 通に得られた特性に闺しては関与の方向性はか なり共通していると言えよう。このことから， 専門家が経検的に重要であると考えている動作 は基本的には類似しているが，その重要度の程 度に拈いて性差があると言えよう。

次に，疾走局面間の差異の有無を検討するた め, 上記の結果と加速疾走局面に扣ける知見(稲 垣ほか23)）との比較を試みた。まず，頭部に関し ては，いずれの局面においても顔や首をリラッ クスすることや額を引くことが重要な方向であ ることが認められた。しかし，中間疾走局面で は視線を固定することを重視するが，加速疾走 局面では視線を徐々に上げることを重視すると いら点で明らかに異なっていた。 上肢部に夙し ては，上肢や肩のリラックス，大きな腕振り， 他の部位との関連性を重視する傾向がいずれの 疾走局面においても認められた。体幹部では， 前傾することや腰を入れることが共通して重視 されている方向であることが認められた。 また， 男子では加速疾走局面では腰を回転させ，中間 庆走では固定することを重視しているといら傾
向が認められた，下肢部に関しては，脚を前後 にまっすぐ回転させることを重視していること が共通して認められた。このように疾走局面に 関しても，共通した特性では重要度評価との関 連の方向性が等しいことが認められた。記の 疾走局面差は，各局面の疾走動作の差異から考 えて当然のことと考えられる。しかし，ここで 明らかにされた重視すへきき動作の疾走局面間差 異は，指導のための具体的な情報を与えてくれ よ5.

以上，本研究で得られた具体的知見は，短距 離走選手といら短距離走動作の専門家の経検的 知識から抽出されたものなので，特に短距離走 の指尊経検の少ない指導者にとっては指導上の 良い指針となるであろ5。しかしながら，本研 究で試みた疾走局面間の比較に関しては，両局 面の標本が一致していないことすあり，さらに， 確認的研究が必要であろ5.

\section{IV. 桔}

短距離走の中間疾走局面の動作に関する経耠 的知識の構造と主観的重要度，及び，その相互 関連性を検討した結果, 以下のような知見が得 られた。

1. 重要度を評価する钼点の数に差異はない。

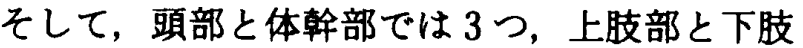
部では 4 つの特性から知識が体制化されてい る。しかし，男女間で動作に関する経呤的知識 の体制化の特性は質的に異なっている。

2. 本研究で設定された各項目の主钼的重要 度は，指学贯や尃門家の教示と類似しており， 専門家の経検的知識を十分反映しているとい5 点からす「経験的重要度」ということが可能で ある。また，多くの項目において主镜的重要度 間に性差があり，さらに，疾走局面間（加速疾 走局面と中間矣走局面）にも差異がある.

3. 主観的重要度は体制化の特性の線形闻数 によって決定されているという棬造を有する。 したがって，体制化の特性は主観的重要度の下 位尺度と位置づけることができる。ま，男女 間で各体制化の特性と主観的重要度の関与の程 
度は異なっているが，男女で共通に認められた 構造化特性の肯定的な極性は同じである.

4. 知識の構造, 主観的重要度, および両者の 関倸は疾走局面によって異なっている。しかし， 共通に得られた構造化特性の肯定的な方向性は はとんど同じである。

的辞：本研究では，調查の実施にあたり筑波大学 陸上競技部前部長，関岡康雄教授をはじめ，多くの 大学の陸上競技部の部長, 監督, コ一チの方々の御 協力を得ました。 また，多くの陸上競技部員の方に 質問紙調查に協力して頂きました。これらの方々に 対し，潹く感謝の意を表します。

\section{文献 (References)}

1) Adams, J.A. (1971) A closed loop theory of motor learning. Journal of Motor Behavior 3: 111-150.

2) Adams, J.A. (1976) Issues for a closed loop theory of motor learning. In : Stelmach, G.E. (Ed.) Motor control: Issues and trends. Academic Press: New York, pp. 87-107.

3) Arabie, P. (1978) Random versus rational strategies for initial configuration in nonmetric multidimensional scaling. Psychometrika $43: 111$ $-113$.

4) Burt, C. (1948) The factorial study of temperamental traits. BJP Statistics Section $1: 178-208$.

5) Clark, A.K. (1976) Re-evaluaton of Monte Carlo studies in nonmetric multidimensional scaling. Psychometrika $41: 401-403$.

6) Cooper, L.G. (1972) A new solution to the additive constant problem in metric multidimensional scaling. Psychometrika $37: 311-322$.

7) de Leeuw, J. and Heiser, W. (1977) Convergence of correction matrix algorithms for multidimensional scaling. In : Lingoes, J.C. (Ed.) Geometric representation of relational data. Mathesis Press: Ann Arbor, Michigan, pp. 735-752.

8) Duda, R.O., Gaschnig, J.G. and Hart, P.E. (1979) Model design in the PROSPECTOR consultant system for mineal exploration. In: Michie, D. (Ed.) Expert systems in the micro-electronic age. Edinburgh University Press: Edinburgh, pp. 153 -167 .

9) Feigenbaum, E.A. (1977) The art of artificial intelligence : Themes and case studies of knowledge engineering. IJCAI $5: 1014-1029$.
10) Guttman, L. (1968) A genaral non-metric technique for the finding the smallest coordinate space for a configuration of points. Psychometrika 33: 469-506.

11）稲垣 教·宮下 愙・大沢清二・松浦義行（1985）短 距兓走における技術イメージの㭗造. 日本体育学会 第 36 回大会号 656 .

12）稲垣 㜞·宮下 告・大沢清二・松浦義行（1986）短 距漓走の技術に関するイメージの個人差と種目間 差. 日本体育学会第 37 回大会号 372 .

13) Inagaki, A., Matsuura, Y., Ohsawa, S. and Miyashit, $k$. (1986) The evaluation of information on skills of sprint running. 1986 Asian Games Scientific Congress Abstracts 183-184.

14）稲垣 敦・宮下 慧・大沢清二・松浦義行（1987）短 距崔走の技術に関するイメージの重要度評価の試 及。棟体育学会第 38 回大会号 388 .

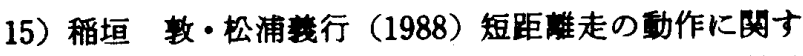
る主锶的情報の䨀造。いばらき体育・スボーツ科学 $3: 35-43$.

16) Inagaki, A. and Matsuura, Y. (1988) A comparative study on the structure of subjective information regarding movement of sprint running among sprinters, distance runners, jumppers and throwers. 1988 Seoul Olympic Games Scientific Congress Proceedings 2: 766-772.

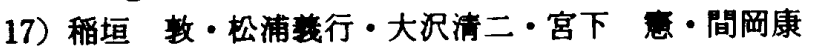
雄（1988）短距離走の動作に成する意識のバタン の㭗造とその変化. 日本体育学会第 39 回大会号 561.

18）稲垣 敦・松浦義行（1989）短距雄走の動作に関す

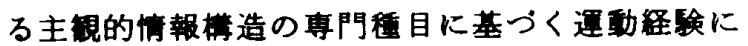
上る差異。いばらき体育・スボーッ科学 4:1ー11.

19）稲垣 數・松浦義行（1989）短距離走の動作に関す る主钼的情報棬造のパフォマンスレベルによる差 異. 日本体育学会第 40 回大会号 228 .

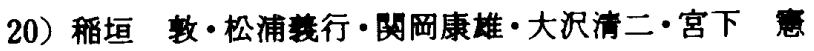

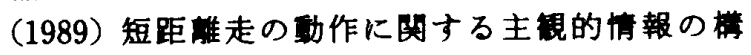
造. 体育学研究 34(3): 201-214.

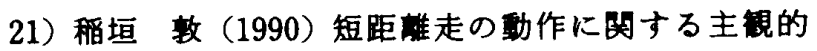
情報の研究. 未発表学位論文. 筑波大学.

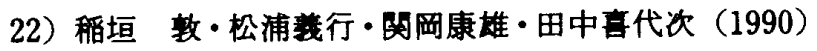

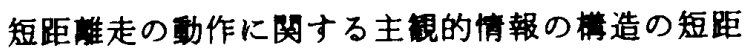
陆走能力による差異. ランニンク学研究 $1: 15$ -30 .

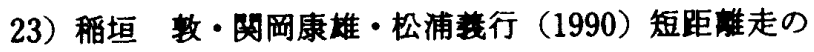
動作に阙する主粯的棈報の研究。陸上競技研究 2 : $30-45$.

24) Kaiser, H.F. (1958) The varimax criterion for analytic rotation in factor analysis. Psychometrika 23 : $187-200$. 
25) Krane, W.R. (1978) Least squares estiamtion of individual differences in multidimensional scaling. Britsh Journal of Mathematical and Statistical Psychology 31 : 193--208.

26) Kruskal, J.B. (1964) Multidimensional scaling by optimizing goodness of fit to a nonmetric hypothesis. Psychometrika $29: 1-29$.

27) Kruskal, J.B. (1964) Nonmetric multidimensional scaling: A numerical method. Psychom. etrika 29 : 115-129.

28) Kruskal, J.B. and Wish, M. (1978) Multidimensional scaling. SAGE; Beverly Hills, California, p. 56 .

29) Lindsay, R.K., Buchana, B.G., Feigenbaum, E.A. and Lederberg, J. (1980) Applications of artificial intelligence for organic chemistry : The DENDRAL project. McGraw-Hill : New York.

30) Lingoes, J.C. and Roskam, E.E. (1973) A mathematical and empirical analysis of two multidimensional scaling. Psychometrika Monograph Supplement $38: 1-93$.

31) McDermott, J. (1981) R1: The formative years. A1 Magazine 2(2): 21-29.

32) Neisser, U. (1976) Cognition and reality. Freeman : San Francisco.

33) Popople, H.E., Myers, J.D. and Miller, R.A. (1975) DIALOG ; A model of diagnostic logic for internal medicine. IJCAI $4: 848-855$.

34) Poulton, E.C. (1957) On prediction in skilled movements. Psychological Bulletin 54 : 467-478.

35) Schönemann, P.H. and Carroll, R.M. (1970) Fitting one matrix to another under choice of a central diration and rigid motion. Psychometrika
$35: 245-255$.

36) Schmidt, R.A. (1970) A schema theory of discrete motor skill learning. Psychological Reviews 82(4) : 255-260.

37) Schmidt, R.A. (1976) The schema as a solution to some persistence problems in motor learning. In : Stelmach, G.E. (Ed.) Motor control : Issues and trends, Academic Press: New York, pp. 41 -65 .

38) Spence, I. (1972) Monte carlo evaluaton of three nonmetric multidimensional scaling algorithms. Psychometrika 13 : 119-157.

39) Spence, I. (1974) On the random ranking studies in nonmetric saling. Psychometrika $39: 267-268$.

40) Spence, I. and Young, F.W. (1978) Monte Carlo studies in nonmetric scaling. Psychometrika 43 : $115-117$.

41）高根芳雄（1980）多次元尺度構成法. 東京大学出版 会：東京。

42) Torgerson, W.S. (1952) Multidimensional scaling: I. Theory and method. Psychometrika 17 . 401-419.

43) Tucker, L.R. (1951) A method for synthesis of factor analysis studies. Personal Research Sec. tion Report No. 984. Department of Army: Washington, D.C., p. 43.

44) Wringley, C. and Neuhaus, J.O. (1955) The matching of two sets of factors. Contract Report A-32 Task A, University of Illinois: Urbana, Illinois, p. 13. 